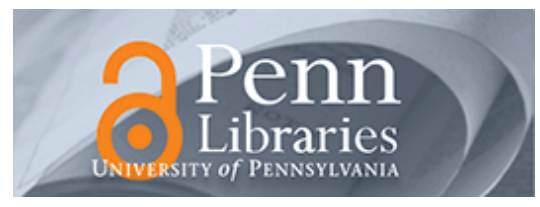

University of Pennsylvania ScholarlyCommons

\title{
Time is Money: Rational Life Cycle Inertia and the Delegation of Investment Management
}

Hugh Hoikwang Kim

Raimond Maurer

Olivia S. Mitchell

University of Pennsylvania

Follow this and additional works at: https://repository.upenn.edu/bepp_papers

Part of the Business Commons, Economics Commons, and the Public Affairs, Public Policy and Public Administration Commons

\section{Recommended Citation}

Kim, H. H., Maurer, R., \& Mitchell, O. S. (2016). Time is Money: Rational Life Cycle Inertia and the Delegation of Investment Management. Journal of Financial Economics, 121 (2), 427-447.

http://dx.doi.org/10.1016/j.jfineco.2016.03.008

(C) 2016. This manuscript version is made available under the CC-BY-NC-ND 4.0 license http://creativecommons.org/licenses/by-nc-nd/4.0/

This paper is posted at ScholarlyCommons. https://repository.upenn.edu/bepp_papers/59

For more information, please contact repository@pobox.upenn.edu. 


\title{
Time is Money: Rational Life Cycle Inertia and the Delegation of Investment Management
}

\begin{abstract}
Many households display inertia in investment management over their life cycles. Our calibrated dynamic life cycle portfolio choice model can account for such an apparently 'irrational' outcome, by incorporating the fact that investors must forgo acquiring job-specific skills when they spend time managing their money, and their efficiency in financial decision making varies with age. Resulting inertia patterns mesh well with findings from prior studies and our own empirical results from Panel Study of Income Dynamics (PSID) data. We also analyze how people optimally choose between actively managing their assets versus delegating the task to financial advisors. Delegation proves valuable to both the young and the old. Our calibrated model quantifies welfare gains from including investment time and money costs as well as delegation in a life cycle setting.
\end{abstract}

\section{Keywords}

portfolio inertia, life cycle saving, household finance, human capital, financial advice

Disciplines

Business | Economics | Public Affairs, Public Policy and Public Administration

\section{Comments}

(C) 2016. This manuscript version is made available under the CC-BY-NC-ND 4.0 license

http://creativecommons.org/licenses/by-nc-nd/4.0/ 
NBER WORKING PAPER SERIES

\title{
TIME IS MONEY: LIFE CYCLE RATIONAL INERTIA AND DELEGATION OF INVESTMENT MANAGEMENT
}

\author{
Hugh Hoikwang Kim \\ Raimond Maurer \\ Olivia S. Mitchell \\ Working Paper 19732 \\ http://www.nber.org/papers/w19732 \\ NATIONAL BUREAU OF ECONOMIC RESEARCH \\ 1050 Massachusetts Avenue \\ Cambridge, MA 02138 \\ December 2013
}

The authors are grateful for research support provided by NIH/NIA Grant \# P30 AG12836 and NIH/NICHD Population Research Infrastructure Program R24 HD-044964, and the Pension Research Council/Boettner Center for Pensions and Retirement Security at the University of Pennsylvania. The authors also received research funding from the Metzler Exchange Professor program at the Goethe University of Frankfurt and the Special Research Fund at the SKK GSB, SKK (Sungkyunkwan) University. Without implicating them, we appreciate helpful comments from Santosh Anagol, Alex Gelber, Itay Goldstein, Dana Kiku, David Love, Jialun Li, David Musto, Stijn Van Nieuwerburgh, Greg Nini, Kent Smetters, Robert Stambaugh, Jeremy Tobacman, Steve Utkus, Jacqueline Wise, and Jessica Wachter. The Wharton High Performance Computing Platform provided an excellent setting for our main numerical analysis. All opinions, findings, interpretations, and conclusions represent the views of the authors and not those of the affiliated institutions or the National Bureau of Economic Research.

At least one co-author has disclosed a financial relationship of potential relevance for this research. Further information is available online at http://www.nber.org/papers/w19732.ack

NBER working papers are circulated for discussion and comment purposes. They have not been peerreviewed or been subject to the review by the NBER Board of Directors that accompanies official NBER publications.

(C) 2013 by Hugh Hoikwang Kim, Raimond Maurer, and Olivia S. Mitchell. All rights reserved. Short sections of text, not to exceed two paragraphs, may be quoted without explicit permission provided that full credit, including $(\mathcal{C}$ notice, is given to the source. 
Time is Money: Life Cycle Rational Inertia and Delegation of Investment Management Hugh Hoikwang Kim, Raimond Maurer, and Olivia S. Mitchell

NBER Working Paper No. 19732

December 2013, Revised March 2015

JEL No. D1,D11,D12,D13,D14,D91,G11,J14,J22,J26

\begin{abstract}
$\underline{\text { ABSTRACT }}$
This paper incorporates two empirically-grounded insights into a dynamic life cycle portfolio choice model: the fact that investors forego the opportunity to accumulate job-specific skills when they spend time managing their own money, and the observation that efficiency in financial decision making varies with age. Our calibrated model demonstrates that both factors generate sensible portfolio inactivity patterns consistent with empirical evidence. We also analyze how people optimally choose between actively managing their assets versus delegating the task to financial advisors. Delegation proves valuable to both the young and the old. Our calibrated model quantifies welfare gains from including investment time and money costs as well as delegation in a life cycle setting.
\end{abstract}

Hugh Hoikwang Kim

SKK Graduate School of Business, Finance Area

Sungkyunkwan (SKK) University

25-2 Sungkyunkwan-ro, Seoul

110-745, Korea

h.kim@skku.edu

Raimond Maurer

Goethe University

Finance Department

Grüneburgplatz 1 (Uni-PF. H 23)

60323 Frankfurt am Main

Germany

maurer@finance.uni-frankfurt.de
Olivia S. Mitchell

University of Pennsylvania

Wharton School

3620 Locust Walk, St 3000 SH-DH

Philadelphia, PA 19104-6302

and NBER

mitchelo@wharton.upenn.edu 


\section{Time is Money: Rational Life Cycle Inertia and the Delegation of Investment Management}

\section{Introduction}

Investor inertia, or the tendency to maintain one's investment portfolio for long periods of time without changing it, has been interpreted as evidence of irrationality or financial illiteracy. ${ }^{1}$ In the present paper, by contrast, we incorporate the opportunity cost of time associated with investment management and show that such inertia can be consistent with optimal behavior. Additionally, we explain why some investors rationally delegate the responsibility to make their investment decisions to a financial advisor. To this end, we develop a life cycle model with rational agents that generates household portfolio inertia patterns consistent with much empirical evidence. ${ }^{2}$ In a dynamic consumption and portfolio framework with endogenous labor supply, we account for time costs devoted to portfolio management. This time becomes particularly valuable when the individual has the opportunity to accumulate job-specific human capital via learning by doing. Our structure for financial decision making costs also posits an age-related time efficiency pattern for financial decision making, in keeping with empirical evidence in Agarwal et al. (2009), Gamble et al. (2014), and Horn and Cattell (1967). We also evaluate the role of financial advisors who, for a fee, help investors manage their financial portfolios. This possibility enables individuals to invest in their job-related human capital and thus to enhance lifetime earnings.

Several prior studies on portfolio choice have shown that people rarely alter their financial portfolios. For instance, Bilias et al. (2009) analyzed investor trading behavior in the

\footnotetext{
${ }^{1}$ See Van Rooij, Lusardi, and Alessie 2011; related work includes Lusardi and Mitchell (2014) and Mitchell, Mottola, Utkus, and Yamaguchi (2006).

${ }^{2}$ See for instance Bilias et al. (2009), and Brunnermeier and Nagel (2008).
} 
Panel Study of Income Dynamics (PSID) and found that most of stock account owners (up to 70\%) exhibited portfolio inertia. They also showed that portfolio inertia followed a U-shaped profile over the life cycle because younger workers owned almost no stock, while older persons who did have assets traded them infrequently. Ameriks and Zeldes (2004) studied TIAA-CREF accountholders over a dozen years, and they noted that $73 \%$ of investors never changed their asset allocation at all, and another 14\% rebalanced only once. Agnew et al. (2003) also reported substantial inertia among investors, particularly in their retirement accounts with close to $90 \%$ never altering their portfolios. Similarly a 2008 survey commissioned by the SEC Office of Investor Education and Advocacy (OIEA) asked investors how often they traded stocks, bonds, or mutual funds (outside employer-sponsored retirement accounts), and they found that over 70\% of investors changed their investment allocations at most once a year. In other words, inertia is the norm for a wide range of investors. ${ }^{3}$

Notwithstanding this evidence, a large body of research on household finance has focused on optimal dynamic portfolio allocation patterns selected by rational forward-looking consumers who decide on their own how to allocate their wealth between stocks and bonds. ${ }^{4}$ This approach has been extended to include flexible labor supply decisions. ${ }^{5}$ Building on these prior studies, we focus on how the opportunity cost of time devoted to investment management influences portfolio choice, in the context of endogenous human capital accumulation. This allows us to diagnose reasons for portfolio inertia and the demand for financial advisors over the life cycle.

\footnotetext{
3 For additional evidence on this point, see Agnew et al. (2003); Ameriks and Zeldes (2004); Bilias et al. (2009); Calvet et al. (2009); Choi et al. (2002); Dellavigna and Pollet (2008); the Economist (2011); Madrian and Shea (2001); and Tang et al. (2010). Barber and Odean (2000) did find evidence of churning among some account holders at a large discount brokerage company in 1996, yet their unusual sample is not characteristic of typical investors.

${ }^{4}$ C.f. Cocco et al. (2005); Gomes and Michaelidis (2003); Horneff et al. (2009); and Cocco and Gomes (2012).

5 Among these are Bodie, Merton, and Samuelson (1992); Chai et al. (2011); and Gomes et al. (2008).
} 
When investors cannot delegate, young and old investors optimally exhibit inertia, while middle-aged investors are more active. This is because the young workers have little job-specific human capital and have the longest time horizon, so they prefer to invest in work skills and exhibit portfolio inertia. Accordingly, they optimally stay out of the stock market and exhibit inertia in non-participation. Middle-aged investors with more job-specific human capital have lower opportunity costs of financial investment. Newly-retired individuals are more active in managing their portfolios because they no longer forego learning on the job, and they must also optimally withdraw from their financial accounts before rising inefficiency in portfolio management and growing mortality risk set in. Later in retirement, older persons are less involved in trading their financial assets, because growing mortality risk and falling decision making efficiency render active management costly. Accordingly, different portfolio management approaches are optimally chosen over the life cycle depending on the investor's financial and labor market status. We also find that the average equity share of liquid assets is hump-shaped with age, consistent with empirical evidence. ${ }^{6}$

When households have an opportunity to delegate money management, results are rather different. Overall, we see that access to delegation reduces both inertia and active self-management. The delegation option is attractive for both young and old investors. Approximately one-quarter (25\%) of investors younger than age 30, $20 \%$ of middle-aged investors (age 30-65), and around $40 \%$ of retirees now optimally delegate to financial advisors. Moreover, access to delegation substantially reduces active management, especially among the youngest and oldest investors. Active management is adopted by only a small fraction (less than $1 \%$ ) of the youngest and oldest investors, but by many more of the middle-aged (around 30\%)

\footnotetext{
${ }^{6}$ See for example Ameriks and Zeldes (2004) and U.S. Census Bureau (2012)
} 
and early retirees ( 50\%). Early retirees are the most active investor group because they have no opportunity cost of forgone labor supply and must optimally withdraw from their financial accounts to cover consumption. Rather than paying a delegation fee, they instead actively manage their finances by withdrawing on their own. Later in life, retirees are more likely to delegate and become less active due to increased mortality risk and decision making inefficiency.

One of our primary research contributions is to model portfolio inertia of individuals who have free access to the stock market yet still do not touch their portfolios over long periods of time. $^{7}$ That is, unlike studies on equity market participation (e.g., Gomes and Michaelides 2005; Vissing-Jorgensen 2003), we show that, while most individuals (57\% in our model) rationally elect inertia unconditional on stock ownership, many (47\%) of stock investors also elect portfolio inertia. In comparative statics analysis, we also evaluate how initial market participation costs influence portfolio inertia patterns, and we show such an initial cost need not produce portfolio inertia among equity owners.

To assess welfare gains of having access to a finanical advisor, we compute the change in the certainty-equivalent (CE) consumption stream when investors do versus do not have access to delegation. Using our baseline fee structure, investors having access to financial advice enjoy greater lifetime welfare by the equivalent of a $1.2 \%$ improvement in their annual consumption streams. We also conduct a sensitivity analysis for different costs of financial advice, to evaluate investors' potential welfare gains from lowering entry barriers to financial advisory services. We conclude that eliminating a minimum fee for advisory services would enhance welfare by $1.43 \%$, compared to the case where no delegation is available. Overall, lowering the entry barriers to

\footnotetext{
7 This is consistent with a wide range of empirical findings; see Agnew et al.(2003); Ameriks and Zeldes (2004); Brunnermeir and Nagel (2008); Calvet et al. (2009a; 2009b); and Dahlquist and Martinez (2015).
} 
access financial advisors can help people of all ages (and particularly the young and the old) to better manage their finances and save their scarcest asset, time for accumulating more job-specific skills or enjoying leisure. Our findings have implications for research and policy regarding investment management and financial advice.

In what follows, Section 2 describes our specification of the investor's portfolio problem when the primary opportunity cost of financial management is the time that could otherwise be used for job-related human capital accumulation. Section 3 describes the dynamic portfolio choice problem when invetors have an option to hire financial advisors. Section 4 presents our calibration of parameters and approach to numerical solution of the model. Section 5 illustrates results of investors' portfolio choice problems, first without delegation, and then with the option of hiring a financial advisor. Section 6 provides sensitivity analysis and evaluates the welfare impact of delegation. We conclude with a discussion of implications of our findings for investors, the financial advisory industry, retirement plan sponsors, and policymakers.

\section{Dynamic Portfolio Choice with Inertia}

In this section we specify the investor's problem when allocating his portfolio, on the assumption that active management of financial assets requires individuals to devote time to the process.

\subsection{Financial Decision Making Efficiency and Time Budgets over the Life Cycle}

We posit a consumer dynamically determining his equity share and labor supply over the life cycle, both of which influence his current and future labor income as well as his financial wealth. The individual is endowed with a per-period time available (normalized to 1). Before retirement, he can allocate his time to work in the paid labor market $\left(l_{t}\right)$ to generate income, or to leisure $\left(L_{t}\right)$. His decision period $(t=0,1, \ldots, T)$ is measured in years; at $t=0$ he begins 
his work life at age 20. He also faces mortality risk over the course of his (uncertain) lifetime, with the maximum age (here set to $100, T=80$ ).

An individual who is not a financial expert will need to devote both time and mental resources to the task of financial management (Abel et al. 2013; Campbell et al. 2011). This can be costly, inasmuch as managing financial assets requires collecting and processing information about market conditions (Christelis et al. 2010), analyzing financial products' risk/return characteristics, and evaluating product fee structures (Anagol and Kim 2012). And while there may be a one-time initial entry cost of equity participation (Vissing-Jorgensen 2002), it will still be necessary each period for investors to expend resources to evaluate changing financial market conditions and understand new products (Carlin 2009, Carlin and Manso 2011). This imposes on individuals an opportunity cost each period, inasmuch as labor earnings depend on job-specific skills derived from work experience. ${ }^{8}$

We capture the explicit opportunity cost of adjusting one's portfolio by the fraction of time $\left(\phi_{t}\right)$ that is devoted to financial decision making. Someone who is not well-informed about financial markets will need to allocate more time to acquire and process information about his portfolio. Accordingly, the investor faces the following time budget constraint:

$$
l_{t}+L_{t}+\phi_{t} \mathbf{1}_{\left\{a_{t}=1\right\}}=1
$$

where $a_{t}$ is a variable taking the value of 1 if he actively manages, and 0 otherwise. This time constraint implies that the investor can make use of his time to either work or enjoy leisure, if he elects not to actively manage his financial portfolio.

\footnotetext{
8 There is a vast literature on on-the-job skill acquisition; see for instance Arrow (1962), Becker (1964), Lucas (1988), and Levitt et al. (2013) among others. Some people may enjoy self-management or believe they can outperform the market as well as professional investors, though few actually do so in practice: their performance is often worse than average (Barber and Odean 2000, Lusardi and Mitchell 2007, Mitchell et al. 2009). Additionally, peoples' portfolio allocations across mutual funds often produces lower returns due to infrequent rebalancing (Frazzini and Lamont 2008).
} 
We also posit that the time cost of making an efficient financial decision $\phi_{t}$ can vary with age. Consistent with the economics and neuroscience literatures on decision making (Horn and Cattell 1967; Agarwal et al. 2009), we suppose that middle-aged investors are more efficient in managing their wealth than are younger or older individuals. Accordingly, we model the age-dependent time cost of financial management as a U-shaped function over the life cycle with the highest efficiency (i.e., lowest $\phi_{t}$ ) in middle age. ${ }^{9}$ This reflects the fact that the young are cognitively able but inexperienced in the labor force; also older workers have job experience but may have diminished cognitive ability. Middle-aged investors tend to be at their best, having gained job experience and not yet experienced cognitive decline. Nevertheless, as investors incur time costs period when they manage their financial portfolios actively, ${ }^{10}$ there is no assumed value of experience in financial management (Chiang et al. 2011).

\subsection{The Human Capital Accumulation Process}

We posit that job-specific human capital is accumulated through learning by doing. In keeping with Arrow (1962) and Becker (1964), we denote with $H_{t}$ and $l_{t}$, respectively, as the time devoted to developing job-specific human capital and work time each period. The law of motion for job-specific human capital is:

$$
H_{t+1}=\left[\left(1-\delta_{t}\right) H_{t}+F_{t}\left(H_{t}, l_{t}\right)\right] \times \lambda_{t},
$$

where $F_{t}\left(H_{t}, l_{t}\right)$ is an experience formulation function and $\delta_{t}$ is a depreciation rate ${ }^{11}$ for job-specific human capital. An idiosyncratic temporary shock $\left(\lambda_{t}\right)$ also affects the accumulation level of human capital in the next period.

\footnotetext{
${ }^{9}$ Technically, this inefficiency arises from the complexity that the typical investor faces when implementing his choices in a dynamic programming problem; see Johnson et al. (2001).

${ }^{10}$ In our model the agent must re-solve his life cycle model and implement new choices each period, so he incurs new time costs every time he engages in active management.

${ }^{11}$ This can also be interpreted as a rate of skill obsolescence; that is, some knowledge becomes outdated by the advent of new technology.
} 
This formulation makes clear that work in the current period $\left(l_{t}\right)$ not only generates current labor income but also raises the stock of human capital resulting in higher future labor income. Previous research on endogenous labor supply in a dynamic portfolio choice model has incorporated uncertain wage rates as an important source of risk (Bodie et al. 1992, Gomes et al. 2008, Chai et al. 2011), but there the decision to work was assumed to affect only current income. Since in prior models life cycle wage profiles were assumed to be determined only by age and exogenous labor market shocks, those studies implicitly assumed that work time substituted for current leisure time, so the price of leisure was simply the current wage. By contrast, in what follows, we model investors who know that taking time away from work today influences their human capital accumulation and hence future labor earnings. Specifically, we specify the experience acquisition function as follows, following Ben-Porath (1967):

$$
F_{t}\left(H_{t}, l_{t}\right)=a\left(H_{t} \cdot l_{t}\right)^{\theta}
$$

where $a$ is a parameter that represents an individual's efficiency for accumulating human capital. $^{12}$ The elasticity of human capital accumulation $\theta$ is assumed to display decreasing returns to scale $(\theta \in(0,1))$.

\subsection{Labor Income and Asset Returns}

Disposable yearly labor income $\left(E_{t}\right)$ is determined by the individual's job-specific human capital level $\left(H_{t}\right)$, wage shock $\left(Y_{t}\right)$, and labor supply $\left(l_{t}\right)$ :

$$
E_{t}=\left(1-h_{t}\right)\left(1-\tau_{t}\right) l_{t} H_{t} Y_{t} U_{t}
$$

where $h_{t}$ and $\tau_{\mathrm{t}}$ represent housing expenditures and labor income tax, respectively. The level of human capital or job-specific skill $H_{t}$ plays a role similar to the age-specific deterministic wage trend in the life cycle literature (Cocco et al. 2005, Gomes et al. 2008, Hubener 2013 et

\footnotetext{
12 Our notion of human capital is informed by job-specific skills accumulated by working, as in Becker (1964).
} 
al.). ${ }^{13}$ In the present case, however, $H_{t}$ is endogenously accumulated over time (i.e., learning by doing) when the individual works, as per equation (2). The permanent wage shock ( $y_{t} \equiv \log Y_{t}$ ) follows a random walk process and is influenced by an idiosyncratic shock (Carroll 1997, Cocco et al. 2005) $y_{t}=y_{t-1}+\epsilon_{t}^{y}$ where $\epsilon_{t}^{y} \sim$ iid $N\left(-0.5 \sigma_{y}^{2}, \sigma_{y}\right)$. The transitory wage shock $\left(U_{t}\right)$ is $\log$ normally distributed with $\log \left(U_{t}\right) \sim i i d N\left(-0.5 \sigma_{U}^{2}, \sigma_{U}\right)$. After the (exogenous) age-65 retirement age $(t=45)$, the individual stops working $\left(l_{t}=0\right)$ and receives a lifelong pension benefit equal to a fraction of his final labor earnings.

Two asset classes are available for the consumer's investment portfolio: riskless bonds and risky stocks. Bonds have a constant annual real gross return of $R_{f}$ in all periods. The real stock gross return $\left(R_{t}^{S}\right)$ is assumed to be serially independent and identically log normally distributed with parameters $\mu_{S}$ and $\sigma_{S}$, implying that $\log \left(R_{t}^{S}\right) \sim N\left(\mu_{S}, \sigma_{S}\right) .{ }^{14}$ The correlation between the stock log return and the innovation to the permanent wage shock is denoted by $\sigma_{\epsilon S}$. We denote $R_{t+1}^{S}$ as the stock gross return from time $t$ to $t+1$, so that the fraction of the individual's wealth invested in stocks is determined in period $t$, and returns are realized in $t+$ 1. Following Gomes et al. (2003), we consider a proportional rate $\tau_{C}$ applied to all asset returns the household receives. Therefore the after-tax bond return is given by $\bar{R}=1+\left(R_{f}-1\right)(1-$ $\left.\tau_{\mathrm{C}}\right)$ and the after-tax stock return is given by $R_{t+1}=1+\left(R_{t+1}^{S}-1\right)\left(1-\tau_{\mathrm{C}}\right)$.

\subsection{Preferences}

As in Gomes et al. (2008), we suppose the investor has a standard time-separable power utility function defined over a composite good consisting of current consumption $\left(C_{t}\right)$ and time

\footnotetext{
13 Indeed below we estimate the parameters of a human capital accumulation process by matching the model-generated moments with that of the age-specific deterministic wage profile in Hubener et al. (2013).

${ }^{14}$ Tang et al. (2010) report that people receive lower returns when they manage their own portfolios, compared to having professionals manage them. For simplicity, we assume that equity returns are the same for all portfolio management methods (inertia, active management, and delegation).
} 
devoted to leisure $\left(L_{t}\right)$, which is given in period by $U_{t}\left(C_{t}, L_{t}\right)=\frac{1}{1-\gamma}\left(C_{t} L_{t}^{\alpha}\right)^{1-\gamma}$. Here $\alpha>0$ captures the investor's preference for leisure relative to consumption. The parameter $\gamma$ measures relative risk aversion.

\subsection{Wealth Dynamics and Portfolio Inertia vs. Active Management}

The investor is assumed to have a stock market account and a bond market account. ${ }^{15}$ In each period $t$, the investor needs to decide how much to consume $\left(C_{t}\right)$ from his available total wealth (or cash on hand, $W_{t}$ ), and how much to invest in the stock market for the next period $\left(S_{t} \geq 0\right)$. The remaining wealth is invested in bonds $\left(B_{t}=W_{t}-C_{t}-S_{t}\right)$. Let $Z_{t}$ be the balance of his stock market account at time $t$. The dynamic budget constraint and evolution of wealth can then be formulated as follows:

$$
\begin{gathered}
W_{t}=C_{t}+S_{t}+B_{t} \\
Z_{t+1}=S_{t} R_{t+1} \\
W_{t+1}=Z_{t+1}+B_{t} \bar{R}+E_{t+1}
\end{gathered}
$$

The stock balance $\left(Z_{t+1}\right)$ in period $t+1$ is determined by his previous period's stock investment choice $\left(S_{t}\right)$ and stock market return $\left(R_{t+1}\right)$. The next period's total wealth $\left(W_{t+1}\right)$ is the sum of realized financial investment (stock account plus bond account balances) and labor earnings $\left(E_{t}\right)$. Depending on how the investor elects next period's stock investment, we have two cases.

\footnotetext{
${ }^{15}$ We could have considered three accounts, namely a brokerage account for stock investment, a savings account for bond investments, and a checking account for consumption as in Abel et. al (2013). In our study, however, the focus is not on the transaction costs of transferring between checking and investment accounts (i.e., stock and bond investment accounts). Moreover, evidence on investor inertia also suggests that investors are not greatly affected by transactions costs (Brunnermeier and Nagel 2008). Additionally, most banks provide free transfers between savings and checking accounts, and money market funds provide bond returns while allowing frequent withdrawals. Thus, here we focus on a case where investors can consume from their total liquid assets (stock+bond+labor earnings) and incur time costs when collecting or processing information to manage their stock/bond portfolios.
} 
Inertia $\left(\boldsymbol{S}_{\boldsymbol{t}}=\boldsymbol{Z}_{\boldsymbol{t}}\right)$ : The investor exhibits portfolio inertia in period $t$ when he retains his current stock balance for the next period. This is equivalent to passively electing the current stock balance as his new investment choice $\left(S_{t}=Z_{t}\right)$, i.e. there are no withdrawals from or new investments into the stock account. In so doing, he incurs no time cost for financial decision making $\left(\phi_{t}=0\right)$ that he would otherwise devote to collecting and analyzing new financial information to implement the change. Accordingly, someone electing portfolio inertia has the following budget and time constraints:

$$
\begin{gathered}
W_{t+1}=Z_{t} R_{t+1}+B_{t} \bar{R}+E_{t+1} \\
l_{t}+L_{t}=1 \\
Z_{t+1}=Z_{t} R_{t+1}
\end{gathered}
$$

Also, when electing inertia, the investor does not finance his current consumption by liquidating part of his stock account, which makes the consumption constraint more binding $\left(\mathrm{C}_{\mathrm{t}} \leq W_{t}-\mathrm{Z}_{\mathrm{t}}\right)$. Of course his next-period balance in the stock account $\left(Z_{t+1}\right)$ may differ from that of the prior period $\left(Z_{t}\right)$ because of uncertain investment returns $\left(R_{t+1}\right)$.

Active management $\left(\boldsymbol{S}_{\boldsymbol{t}} \neq \boldsymbol{Z}_{\boldsymbol{t}}\right)$ : The investor exhibits active portfolio management in period $t$ when he explicitly chooses an investment amount in stocks; that is, he makes additional investments into or takes withdrawals from his stock account based on his investment decisions. Accordingly, the amount invested in stocks for the next period can differ from the current stock balance $\left(S_{t} \neq Z_{t}\right) .{ }^{16}$ In return, the investor must incur (age-dependent) time costs $\left(\phi_{\mathrm{t}}>0\right)$ in this period. ${ }^{17}$ The wealth and time budget constraints evolve as follows:

\footnotetext{
${ }^{16}$ Conceptually it would be possible for an active investor to choose to buy and sell exactly the same amount as his current stock balance, but this case is not interesting from a modeling perspective and eliminated in the optimization process of investors.

17 The recurring time cost (or cognitive attention/resources) for gathering and processing information for financial management is also consistent with a recent literature on optimal inattention and economic decision making (e.g.,
} 


$$
\begin{gathered}
W_{t+1}=S_{t} R_{t+1}+B_{t} \bar{R}+E_{t+1} \\
l_{t}+L_{t}+\phi_{\mathrm{t}}=1 \\
Z_{t+1}=S_{t} R_{t+1}
\end{gathered}
$$

Optimization: By defining inertia as a situation where the investor does not alter his stockholdings, we treat the stock account balance $\left(Z_{t}\right)$ as a state variable within a dynamic optimization framework. This is because it is necessary for the investor to know his current stock balance before deciding whether to leave it as is (i.e., $S_{t}=Z_{t}$ ), or to actively evaluate some different allocation. Other state variables include total wealth $\left(W_{t}\right)$, accumulated human capital $\left(H_{t}\right)$, and the wage shock $\left(y_{t}\right)$. There are also four choice variables: the portfolio management method (i.e., portfolio inertia or active management), labor supply $\left(l_{t}\right)$, stock holdings going into the next period $\left(S_{t}\right)$, and consumption $\left(C_{t}\right)$.

Because the portfolio management method is a discrete choice variable, we formulate the investors' problem in a dynamic discrete choice model (Adda and Cooper 2000). We define $V_{t}^{a}\left(W_{t}, H_{t}, Z_{t}, y_{t}\right)$ as the investor's discounted lifetime utility when he actively manages his portfolio; similarly, $V_{t}^{i}\left(W_{t}, H_{t}, Z_{t}, y_{t}\right)$ denotes his discounted lifetime utility when he elects portfolio inertia. Then the value function at time $t$ is specified as:

$$
V_{t}\left(W_{t}, H_{t}, Z_{t}, y_{t}\right) \equiv \max \left\{V_{t}^{a}\left(W_{t}, H_{t}, Z_{t}, y_{t}\right), V_{t}^{i}\left(W_{t}, H_{t}, Z_{t}, y_{t}\right)\right\}
$$

Let $\beta<1$ be the investor's time preference and $p_{t}$ the probability that he survives to the next period. Then the value function for active management is as follows: ${ }^{18}$

\footnotetext{
Abel et al., 2013, Sims 2003), learning (Sargent 1993, Evans and Honkapohja 2001), and robust control (e.g., Giannoni 1999, Hansen and Sargent 2001, Onatski and Stock 1999).

${ }^{18}$ We could introduce a direct transaction cost $T C\left(S_{t}, Z_{t}\right)$ for portfolio adjustment, in which case the equation for total wealth would be $\mathrm{W}_{\mathrm{t}+1}=S_{t} R_{t+1}+B_{t} \bar{R}+E_{t+1}-T C\left(S_{t}, Z_{t}\right) \mathbf{1}_{\text {\{adjustment }}$. Nevertheless, we do not focus here on direct monetary costs; see Bonaparte and Cooper (2009) and Campanale et al. (2012) for more on that approach.
} 


$$
\begin{gathered}
V_{t}^{a}\left(W_{t}, H_{t}, Z_{t}, y_{t}\right)=\max _{\left\{C_{t}, S_{t}, l_{t}\right\}} U_{t}\left(C_{t}, L_{t}\right)+p_{t} \beta \mathbb{E}_{t}\left[V_{t+1}\left(W_{t+1}, H_{t+1}, Z_{t+1}, y_{t+1}\right)\right] \\
\text { s.t. } W_{t}=C_{t}+S_{t}+B_{t} \\
W_{t+1}=S_{t} R_{t+1}+B_{t} \bar{R}+E_{t+1} \\
H_{t+1}=\left[\left(1-\delta_{t}\right) H_{t}+F_{t}\left(H_{t}, l_{t}\right)\right] \lambda_{t} \\
Z_{t+1}=S_{t} R_{t+1} \\
l_{t}+L_{t}+\phi_{t}=1 .
\end{gathered}
$$

The value function for portfolio inertia is as follows:

$$
\begin{gathered}
V_{t}^{i}\left(W_{t}, H_{t}, Z_{t}, y_{t}\right)=\max _{\left\{C_{t}, l_{t}\right\}} U_{t}\left(C_{t}, L_{t}\right)+p_{t} \beta \mathbb{E}_{t}\left[V_{t+1}\left(W_{t+1}, H_{t+1}, Z_{t+1}, y_{t+1}\right)\right] \\
\text { s.t. } W_{t}=C_{t}+Z_{t}+B_{t} \\
W_{t+1}=Z_{t} R_{t+1}+B_{t} \bar{R}+E_{t+1} \\
H_{t+1}=\left[\left(1-\delta_{t}\right) H_{t}+F_{t}\left(H_{t}, l_{t}\right)\right] \lambda_{t} \\
Z_{t+1}=Z_{t} R_{t+1} \\
l_{t}+L_{t}=1 .
\end{gathered}
$$

When an investor elects portfolio inertia, he does not need to re-maximize the value function with respect to stock holdings; instead, he takes his current stock balance $\left(Z_{t}\right)$ as his next period's stock investment $\left(\mathrm{S}_{\mathrm{t}}\right)$. If $V_{t}^{a} \geq V_{t}^{i}$, the investor opts for active management $\left(a_{t=1}\right)$; otherwise, he opts for portfolio inertia.

The two value functions differ due to their different time constraints and next period's portfolio choice. The appeal of portfolio inertia is that the time saved can then be used either to work and accumulate more human capital, thereby raising future earnings, or to enjoy more leisure. During retirement, the investor does not work, so if he decides to actively manage his 
portfolio, he sacrifices only his leisure time. Later in retirement, decreasing financial decision making efficiency and rising mortality risk make inertia more appealing. ${ }^{19}$

\section{The Role of Financial Advisors and Dynamic Portfolio Choice with Delegation}

Next we extend the model to examine how introducing financial advisors can add value to life cycle decision makers. Reasons for delegating portfolio management can include time costs, efficiency gains due to lower transaction costs, and beliefs regarding professional managers' skills. In what follows, we focus mainly on the investor's forgone opportunity to accumulate more human capital associated with active management during the work life.

When an investor elects to delegate his portfolio management to an advisor, he must pay a management fee from his wealth $\left(W_{t}\right)$. In the financial advisory service industry, the fee generally consists of a minimum fixed fee $\left(\varphi_{\min }\right)$ plus a percentage fee $\left(\varphi_{p t g}\right)$ charged on total assets under management. ${ }^{20}$ Formally, this structure may be expressed as follows:

$$
\varphi_{t}=\max \left(\varphi_{\min }, \varphi_{p t g} W_{t}\right)
$$

The financial advisor not only selects the individual's investment portfolio, but he also proposes optimal levels of consumption and labor supply that are in the client's best interest. ${ }^{21}$ The value function for the delegated portfolio management method is then:

$$
\begin{gathered}
V_{t}^{d}\left(W_{t}, H_{t}, Z_{t}, y_{t}\right)=\max _{\left\{C_{t}, S_{t}, l_{t}\right\}} U_{t}\left(C_{t}, L_{t}\right)+p_{t} \beta \mathbb{E}_{t}\left[V_{t+1}\left(W_{t+1}, H_{t+1}, Z_{t+1}, y_{t+1}\right)\right] \\
\text { s.t. } W_{t}=C_{t}+S_{t}+B_{t}+\varphi_{\mathrm{t}} \\
W_{t+1}=S_{t} R_{t+1}+B_{t} \bar{R}+E_{t+1}
\end{gathered}
$$

19 Sufficient conditions for the selection of portfolio inertia are discussed in Appendix B.

20 See Appendix A for a dicussion of the fee structures usedby SEC-registered investment advisors (RIA) in the U.S.

21 We do not model a possible conflict of interest between clients and financial advisors, which was analyzed by Sharpe (1985), Stoughton et al. (2011), Ou-Yang (2003), and Mullainathan et al. (2012), among others. 


$$
\begin{gathered}
H_{t+1}=\left[\left(1-\delta_{t}\right) H_{t}+F_{t}\left(H_{t}, l_{t}\right)\right] \times \lambda_{t} \\
Z_{t+1}=S_{t} R_{t+1} \\
l_{t}+L_{t}=1
\end{gathered}
$$

Note that the investor pays the management fee $\varphi_{t}$ out of his total wealth, but he does not incur any time cost $\phi_{t}$. The advantage of hiring the financial advisor is either more leisure or the saved time which can then be used to work and accumulate more job-specific knowledge.

Accordingly, the investor's optimization problem of finding the best portfolio management method can be summarized as:

$$
\begin{gathered}
V_{t}\left(W_{t}, H_{t}, Z_{t}, y_{t}\right) \\
=\max _{\left\{a_{t}, l_{t}, S_{t}, C_{t}\right\}} U_{t}\left(C_{t}, L_{t}\right)+p_{t} \beta \mathbb{E}_{t}\left[V_{t+1}\left(W_{t+1}, H_{t+1}, Z_{t+1}, y_{t+1}\right)\right] \\
\text { s.t. } W_{t}=C_{t}+S_{t}+B_{t}+\varphi_{t} \mathbf{1}_{\left\{a_{t=2}\right\}} \\
W_{t+1}=S_{t} R_{t+1}+B_{t} \bar{R}+E_{t+1} \\
H_{t+1}=\left[\left(1-\delta_{t}\right) H_{t}+F_{t}\left(H_{t}, l_{t}\right)\right] \times \lambda_{t} \\
l_{t}+L_{t}+\varphi_{t} \mathbf{1}_{\left\{a_{t=1}\right\}}=1 \\
S_{t}=Z_{t} \text { if } a_{t}=0
\end{gathered}
$$

where $a_{t}=0$ denotes portfolio inertia, $a_{t}=1$ active management, and $a_{t}=2$ hiring a financial advisor. $V_{t+1} \equiv \max \left\{V_{t+1}^{i}, V_{t+1}^{a}, V_{t+1}^{d}\right\}$ where $V_{t+1}^{i}$ is the value function for the portfolio inertia case, $V_{t+1}^{a}$ is the value function for active management, and $V_{t+1}^{d}$ is the value function for delegating portfolio management. 


\section{Model Calibration and Solution}

\subsection{Numerical Procedure for the Model Solution}

In our model, there is no simple Euler equation linking the marginal benefit of today's portfolio adjustment with future marginal benefits, inasmuch as the investor is unsure about which portfolio management method he will select at each point in the future. For this reason, it is intractable to solve the model in a closed form. We therefore solve the model numerically via backward induction, multi-linear interpolation, and Monte-Carlo integration (see Appendix C for details).

\subsection{Parameter Calibration}

We calibrate the model using a reasonable set of base case parameters, setting the discount factor $\beta$ to 0.96 , the coefficient of relative risk aversion to $\gamma=3$, and the leisure preference parameter to $\alpha=1.0$, as is conventional in other life cycle studies (see Gomes et al. 2008; Chai et al. 2011; and Cocco and Gomes 2012). One-period survival rates $p_{t}$ in the utility function are calculated from the 2009 US Social Security Administration Trustees Report cohort mortality table for males born in 1990 (Bell and Miller 2012).

An important element of the model is the human capital accumulation process $\left(H_{t}\right)$, which generates the opportunity cost of time when an investor elects to actively manage his financial assets. As noted above, accumulated human capital serves a similar role as the age-dependent wage profile in prior studies. To this end, we calibrate the human capital accumulation process by matching the model-generated moments with those of an age-dependent wage rate profile for male high school graduates derived from PSID data (as in Hubener et al. 2013). ${ }^{22}$ Based on this

\footnotetext{
${ }^{22}$ Technically, we implement a simulated method of moment procedure (SMM) by numerically minimizing the distance of various moments (i.e., mean, standard deviation, median, skewness, kurtois, max, min and the age of maximum wage) of the simulated human capital accumulation process given in equations (2) and (3) relative to the
} 
moment-matching process, we find that human capital $H_{t}$ depreciates at an annual rate of $\delta_{t}=0.16 \%+0.023595 \times$ year ; the elasticity parameter in the experience accumulation function is set to $\theta=0.0462$; and the accumulation rate to $a=0.7596$. The idiosyncratic shocks to human capital follow an iid lognormal distribution $\ln \left(\lambda_{t}\right) \sim N\left(-0.5 \cdot 0.0434^{2}, 0.0434\right)$. The standard deviation of the permanent wage shock is 0.0710 and the pre-retirement transitory wage shock standard deviation is 0.1726; in retirement it is 0.28 (as in Love 2010). The post-retirement shocks may be interpreted as income or consumption surprises due to unexpected out-of-pocket medical expenses or long-term care expenses.

Retirement benefits are assumed to replace $50 \%$ of the individual's last labor income $E_{t}=0.2 H_{45} Y_{45}(t=45,46, \ldots, T)$. This formulation generates higher (lower) replacement rates for workers with lower (higher) average career earnings, consistent with the progressive benefit rules of the U.S. Social Security system (Chai et al. 2011). The riskless asset return is set to $1.01 \%$ and the risk premium for stocks is $4 \%$ with a standard deviation of $20.5 \%$ (Cocco et al. 2005). Labor income is taxed at 30\% during working period and 15\% after retirement. Capital gains are taxed at 20\%. These rates reflect effective tax rates typical household faces in U.S. (Gomes et al. 2008).

So that the calibration embodies relatively realistic delegation fees, we have collected and analyzed advisory charges of registered investment advisors (RIAs) reporting to the US. Security and Exchange Commissions (SEC). ${ }^{23}$ We focus on retail-oriented advisors charging a percent of total assets under management (AUM), as this is the most common form of fee (see Appendix A

(deterministic) age-dependent wage profile used in the literature (Gomes et al. 2008; Hubener et al. 2013). A more detailed explanation of this procedure appears in Appendix D.

${ }^{23}$ Registered Investment Advisors (RIAs) in the U.S. must file with the Securities and Exchange Commission (SEC) before they can provide advice on financial investments including stocks, bond, and mutual funds. They can also help implement clients’ optimal portfolio choices; see Mitchell and Smetters (2013). See also Appendix A.. 
for more detail). Since these fees average $1.41 \%$ per year, our baseline calibration uses this level $\left(\varphi_{p t g}=1.41 \%\right)$. To cover fixed costs of advisory service, financial advisors often stipulate a minimum balance they require if they are to take on the client for a percentage fee. Below that level, they charge a fixed fee calculated as a set percentage times the minimum required account balance. For retail-oriented advisors, the minimum required account balances average about $\$ 240,000$, which translates into a fixed fee level of $\$ 3,400$. Such a high threshold for delegation will discourage most consumers from delegation in the real world and in our model. ${ }^{24}$ Accordingly, for the baseline case below, we explore investors' choice of a delegation option by setting the minimum fee at $\varphi_{\min }=\$ 2,115$ (commensurate with a minimum required account balance of $\$ 150,000 \times 1.41 \%)$. In sensitivity analysis, we also analyze how different fixed fees affect investor behavior and welfare.

The efficiency function for financial decision making is assumed to be convex, as discussed above. Investors around age 50 are assumed to be most financially savvy with $\phi_{22}=0.03$; that is, they sacrifice only $3 \%$ of their normalized time to manage their own portfolios. Our time cost estimate of $3 \%$ is based on the American Time Use Survey (ATUS 2012), where people spend an average of 0.35 hours a day on financial management, or around 3\% of the 13 hours of daily discretionary time (calculated by deducting time spent on necessary activity such as sleeping, eating/drinking, essential household activities, and caring for household members). Young investors are assumed to be less efficient $\left(\phi_{1}=0.09\right)$ than the middle-aged. The functional form for efficiency is assumed to be $\phi_{t}=\frac{0.09-0.03}{30^{4}}(\mathrm{age}-30)^{4}+0.03$, where the 4th power generates modest efficiency pattern changes around middle-age. In a later section,

\footnotetext{
${ }^{24}$ This is one reason that our baseline model without a delegation option appears realistic for the majority of real-world investors.
} 
we also conduct sensitivity analysis assuming different levels and shapes for the active management inefficiency function. Baseline parameters are summarized in Table 1.

Table 1 here

\section{Results and Discussion}

We next describe investor behavior when no delegation option is available, and after that, we report results when individuals can elect and delegate money matters to a financial advisor. We use the optimal controls of the baseline parameterization to generate 2,000 simulated lifetimes reflecting realizations of stock returns and labor income shocks. All investors begin with a zero stock account balance (i.e., no inheritance, $Z_{i, 1}=0$ ).

\subsection{Profiles for Consumption, Wealth, Earnings, Stock Holdings, and Labor Supply: No Delegation Option}

Figure 1 summarizes our baseline results for the key choice variables (consumption, wealth, labor supply, and earnings) when delegation is not an option. Panel A indicates that the model generates hump-shaped wealth, earnings, and consumption profiles over the life cycle, consistent with those reported in other studies (e.g., Gomes et al. 2008). Consumption drops sharply at age 66 when households retire and begin to consume more leisure. Such a profile is in line with other life cycle models with endogenous work hours (Chai et al., 2011); it is also in line with empirical studies documenting a substantial decline in spending around the retirement date (Battistin et al. 2009). Panel B illustrates the average stock balance which also traces out a hump-shaped pattern over the life cycle. Starting with no stock balance, individuals then invest more in the stock market until they retire, after which they gradually decrease their exposure to stocks. This result is consistent with empirical findings of a hump-shaped equity share profile along with a hump-shaped wealth profile over the life cycle (Ameriks and Zeldes 2004). Panel C 
traces the labor supply pattern which is slightly hump-shaped over time. Average lifetime labor supply equals 0.35 , which corresponds to about 1,820 work hours per year (assuming a time endowment of 100 waking hours per week). This is similar to prior work (see Gomes et al. 2003 and 2008, Chai et al. 2011) and it is also in line with empirical evidence for U.S. workers. ${ }^{25}$. On average, the stock of human capital rises with age, but at a decreasing rate.

Figure 1 here

\subsection{Portfolio Inertia and Equity Choices: No Delegation Option}

Figure 2 shows optimal choice patterns of portfolio management method and equity holdings over the life cycle when delegation is unavailable. Panel A illustrates how people optimally manage their portfolios depending on whether inertia or active management dominates. As is evident, inertia is the dominant strategy for young investors to about age 30; thereafter, active management becomes more prevalent until retirement, whereupon even more switch to active management early in retirement (the fraction of active managing investors rises from around half at age 64 to about 60\% at age 65). Later in life, people again revert to inertia.

Figure 2 here

The reason for this pattern is that the young have little financial wealth, but they will need forgo much human capital investment when they devote time to manage their meager financial assets. They also have a longer horizon over which they can use their human capital to generate labor earnings. Conversely, later in life, people have more wealth and a smaller opportunity cost of time. This is because they have a shorter work lives remaining and have already accumulated substantial human capital. Accordingly, sacrificing a small amount of time to manage their

25 The Bureau of Labor Statistics (BLS Economic releases Table B-2) report average weekly working hours of 34.6 hours. The OECD documents about 1,800 annual working hours for U.S. workers ("http://stats.oecd.org/index.aspx?DataSetCode=ANHRS"), which is similar value reported by Low (2005) using data from the Consumer Expenditure Survey. 
finances has only a modest impact on their wages. Still, however, almost half of the middle-aged group does not change portfolio allocations; such a high level of inactivity is consistent with several empirical studies (Ameriks and Zeldes 2004; Bilias et al. 2009; Calvet et al. 2009a; Mitchell et al. 2007; and Vissing-Jorgensen 2003). Among the older group with lower wealth, their reduced decision making efficiency and increased mortality risk somewhat depresses their interest in active management. Early in retirement, older people are much more likely to switch to active management to rebalance their portfolios, now that they have more free time. The fraction of actively managing investors thus jumps from $50 \%$ at age 64 to about $60 \%$ at age 65 . As time goes by, however, reduced wealth and income shrink the budget constraint for consumption, which in turn reduces utility from actively managing financial assets. Additionally, rising mortality risk boosts their preference for current consumption and leisure. These factors all lead to more inertia later in life.

Our U-shaped pattern of portfolio inertia is compatible with available empirical evidence. For instance, in our model, young investors who start with a zero stock account balance remain out of the stock market (i.e. $S_{t}=Z_{t}=0$ ). This is consistent with results in the PSI from Bilias et al. (2009). Our model also implies that middle-aged and older investors are more likely to particpate in the market, but older investors exhibit more inertia. This conforms to evidence from Bilias et al. (2009) who showed that the conditional probability of inertia is lower for the middle aged, whereas older investors are less likely to trade than the middle-aged even when they hold stocks. ${ }^{26}$ In sum, our baseline settings appear to be in line with empirically-observed U-shaped

\footnotetext{
${ }^{26}$ In an untabulated analysis of our simulated data, we find that young investors, conditional on holding stocks, are more likely to trade compared to middle-aged investors consistent with the PSID data (Bilias et al. 2009).
} 
inertia patterns. Young investors tend not to hold stocks, and older investors do but tend not to trade.

It is also of interest to note that our overall inertia levels are comparable to the empirical findings reported by Bilias et al. (2009). For instance, across all age groups, they find 40-70\% inertia among stock owners (depending on the survey year); our model generates 47\% inertia among those who own stocks (and 57\% unconditional on stock ownership). If we were to use a the narrower definition of inertia meaning no trading in a five-year time span, our model generates 33\% inertia conditional on stock holding, close to the 39-56\% fraction over a five-year period in the data.

Panel B of Figure 2 illustrates the fraction of financial wealth invested in equity changes over the life cycle when no delegation option is available. ${ }^{27}$ The solid line reflects the average fraction in equities for the subgroup of inertia investors. The dotted line refers to the corresponding equity share for active investors (the overall average is indicated by the dashed line). Consistent with most prior life cycle models with uncertain labor income, active investors hold almost $100 \%$ of their savings in equity early in life, and glide down to lower shares as they age. The explanation is that future labor income can be thought of as a implicit bond position, so workers will seek to diversify their overall wealth position consisting of human capital and financial wealth. Conditional on becoming active, they follow the traditional investment strategy recommended by previous life cycle studies (as in Cocco et al. 2005; and Merton 1971). By contrast, inertia investors allocate less to equity when young and invest more in equity when old. This is because young investors start with a zero stock balance and little wealth, so they are more likely to choose inertia and hence invest nothing in equity. As they accumulate wealth, they begin

${ }^{27}$ In our notation, the equity share of each investor is defined as $S_{t} /\left(S_{t}+B_{t}\right)$. 
to manage more actively and accumulate equity. Between age 30 and 60 , the equity fraction of the inertia investor is rather flat, at around $60 \%$. Interestingly, at retirement there is a sharp drop of the equity fraction for inertia investors. The reason is that early retirees reallocate substantial amounts of equities once toward bonds before they start to draw down during retirement. This, in turn, can be explained by the fact that older investors facing rising mortality risk and more inefficiency in financial decision making understand that active financial management implies rising opportunity $\operatorname{costs}^{28}$ Because inertia-investors gradually deplete their wealth from their bond accounts and defer selling off their equity accounts, their equity share increases over time in later years.

Overall, combining the cases of inertia and active-management investors, we observe that the average equity share (the dashed line in Figure 2, Panel B) rises for younger individuals and declines steadily afterwards. Although those electing active management at older ages optimally choose lower equity shares, the fact that older inertia investors retain a high equity share implies that stock holdings do not decline sharply with age. In sum, in our model people optimally do not invest in stocks early in their life, but in middle age they gradually move into stock, and then they curtail stockholdings later in life, while still retaining a reasonable share.

Figure 3 displays scatter plots of stock account balances for active and inertia investors; the solid line indicates average stock balances in each case. It is clear that those active managers hold more in equities than do inertia investors. Individuals having greater equity exposure find it optimal to allocate more time to portfolio management and become active investors. Nevertheless, the average does not imply that all inertia investors eschew equities. In fact, as the right panel in Figure 3 illustrates, a large group of those who are inactive still hold substantial stock positions.

${ }^{28}$ The gradual decumuation of assets from the bond account is not due to time costs, in contrast to transactions from the stock account. 
If an investor expects he will end up choosing a similar consumption/labor supply pair next period, a small change in his portfolio will be costly without enhancing his discounted lifetime utility. In such a case, it will then be optimal for him not to alter his portfolio (Appendix B discusses a sufficient condition for inertia choice).

Figure 3 here

Table 2 illustrates how portfolio inertia and equity trading patterns vary over the life cycle. We also show how patterns differ by wealth level (above and below $\$ 150,000$ ), to illustrate how wealth is related to portfolio management choice and subsequent trading patterns. Some two-thirds (67\%) of the lower wealth middle-aged investors elect inertia, while only one-fifth (20\%) of the same age group with more than $\$ 150,000$ elect inertia. This pattern confirms to our model of the opportunity costs of active financial management: low-wealth investors do not sacrifice time to manage their accounts, while wealthier individuals do. Table 2 also shows that the factors driving active management vary over the work life. Active investors buy stocks while young and sell their stocks while old. In the 20-35 age range, almost two-thirds (62\%) of wealthy investors buy equities seeking to capture the equity premium; in their 60 s and 70 s, almost $60 \%$ actively sell stocks to finance consumption.

Table 2 here

Table 3 presents summary statistics concerning the dynamics of portfolio management methods when no delegation option is feasible. On average, the first time that people elect active management is about nine years after entering the labor force. They elect inertia for 46 years and manage their own portfolios for 34 years, altering their management strategies 12 times over their lifetimes. Some $12 \%$ of people $(=1-[1,767 / 2,000])$ never elect active management and remain inactive throughout their entire lifetimes.

Table 3 here 


\subsection{Portfolio Management: With a Delegation Option}

Next we turn to an evaluation of how portfolio management methods change optimally when a financial advisor is available. Table 4 summarizes results. On average, investors now change their portfolio management approach much more often, almost 19 times over their lives (18.82, versus 11.55 in Table 3), and they elect inertia for a shorter period (44.94 years, versus 45.97 in Table 2). Of most interest is the fact that people devote about half as many years to active management (17.69 versus 34.03 previously), and they engage advisors for just under one-quarter of their adult lives (=17.36 years/80). Investors begin to delegate relatively soon, only 8.39 years from starting work, and about $80 \%$ of people elect to delegate at some point $(79 \%=1,581 / 2,000)$. Additionally, when delegation is an option, fewer choose active management and those who do, begin later, 14.31 years after starting work (versus 8.95 in Table 3).

\section{Table 4 here}

Table 5 shows what happens when investors can delegate their investment management to a financial advisor. Panel A illustrates patterns of portfolio managment methods by age, where we see that access to delegation reduces inertia and active-management, compared to the findings in Figure 2. Delegation is attractive for investors of all ages: approximately $19 \%$ of investors younger than age $35,2 \%$ of middle-aged investors (age 30-65), and around $37 \%$ of old retirees (age $80^{+}$) now optimally delegate to a financial advisor. Access to delegation substantially reduces active management, especially among the youngest and oldest investors. Active management is adopted by only a small fraction of the youngest (8\%) and oldest investors (2\%), but by many more (around 30\%) middle-aged and early retirees (about 50\%). Early retires become the most active investor group because they have no opportunity cost of forgone labor supply and must optimally withdraw from their stock accounts to meet retirement consumption 
needs. Rather than paying a delegation fee, they instead actively manage their stock accounts by withdrawing before mortality risk rises, and prior to a decline in decision making efficiency. Table 5 here

Panel B of Table 5 decomposes portfolio management methods when the delegation option is available. Among those initially electing inertia or active management, younger and older investors are more likely to switch to delegation. Among middle-aged individuals (36-65), active investors are more likely to continue with active management. This pattern is related to the opportunity cost of time. Young investors, who have the longest horizon to earn human capital returns, find it optimal to elect the delegation option. Older investors facing high mortality risk and inefficiency of financial management also favor financial advisors, to save them leisure time. By contrast, middle-aged investors with high wealth and human capital face a lower opportunity cost of time, and hence they will manage their portfolios themselves and avoid paying the delegation fee. Early retirees are more likely to engage in active management as they need not worry about accumulating job-specific skills any more. It should be noted that the decision to delegate among the young and old investors is affected by the assumption regarding a required minimum fixed fee: some inertia investors cannot gain access to financial advisors, as they have insufficient wealth. Below we discuss how lowering the minimum fixed fee shapes investors' decisions to hire an advisor.

Panel C of Table 5 represents the average fraction of savings invested in equities, depending on whether the investor elected inertia, active management, or delegation. For investors choosing active management, the fraction of savings invested in equity follows an age-related glide path consistent with the traditional portfolio choice literature. Inertia investors hold little equity when young and more equity when old, similar to the no delegation case. 
Interestingly, the delegated portfolio also follows a downward-sloping glide path, but the slope is flatter.

Table 6 summarizes changes in behavior when a delegation option is available for wealth, equity share, labor income, labor supply, human capital, and consumption by age. All are expressed as a percent of the no-delegation base case. Results show that having access to an advisor increases wealth by $0.5-1.7 \%$ across age groups. This is due to the higher equity share noted above, and also to spending more time on the job which builds human capital. Having access to an advisor also increases leisure around 2-4\% during the work and about $7 \%$ in retirement, and raises consumption considerably among the young.

Table 6 here

\subsection{Determinants of Portfolio Management Methods}

Next we use descriptive multinomial Logit regressions to summarize the factors associated with investors’ portfolio management methods in our simulated data. Tables 7 and 8 show how the probability of choosing inertia over active management when a delegation option is (or is not) available, is associated to lagged wealth, stock market shocks, and wage shocks.

\section{Tables 7 and 8 here}

When no delegation is feasible, wealthier investors are less likely to engage in inertia as indicated in the first column of Table 7 and consistent with empirical findings (Agnew et al. 2003, Bilias et al. 2008, and Calvet et al. 2009). This is because sticking to a non-optimal level of equity exposure is more costly for them, compared to the less wealthy. The second column indicates that investors experiencing negative stock market shocks and positive wage shocks are more likely to elect portfolio inertia, due to their need to invest more in human capital and avoid risky equity. Investors experiencing good labor market shocks elect inertia rather than actively managing their assets, as their opportunity costs of active management are higher. Having a 
lagged negative stock market shock reduces investor overall wealth, which subsequently decreases their interest in actively managing their portfolios. The third column includes all regressors, and results are similar.

A similar analysis but now allowing delegation is provided in Table 8. Panel A uses active management as the reference group; as before, wealthier individuals are less likely to engage in inertia. Comparing delegation and active management, people with additional wealth would like to choose active management. Although wealthy investors have more need to delegate, they also must pay higher delegation fees; in our model, the cost outweighs the benefits. Negative stock market shocks make inertia more attractive than active management, as before, but they also enhance the appeal of delegation over active management because people find it optimal to pay a delegation fee given their lower wealth rather than incurring the opportunity time cost.

Positive wage shocks lead investors to choose inertia over active management, but they have two offsetting effects on the delegation versus active management decision. A positive wage shock increases the opportunity cost of active management, but it also increases the advisory fee due to higher wealth levels. Our analysis shows that the opportunity cost saving is more influential than the wealth effect. In sum, negative wealth or stock return shocks, or positive labor earnings surprises, lead investors to select inertia or delegation, and to avoid active management.

Panel C of Table 8 uses inertia as the reference group, where we now see that wealthy investors are more likely to choose delegation rather than inertia because suboptimal portfolio choice is more costly to them, compared to their poorer counterparts. Positive stock market surprises increase wealth so the cost of inertia rises, boosting demand for delegation. At the same time, however, this also means they will pay more in fees, due to their greater wealth. In our analysis, these costs and benefits offset each other, so positive stock surprises do not provide an 
unambiguous prediction about the choice between delegation vs. inertia. Investors experiencing a positive labor earnings shock are more likely to choose inertia over delegation.

Comparing Panels A and B of Table 8, we can highlight what drives investors' preferences for the three portfolio management methods given shocks. Favorable wealth shocks lead to an overall preferred ordering of active management, delegation, and inertia. Positive stock surprises make active management more attractive than delegation or inertia, without a clear ranking of the latter two methods. In response to a favorable labor earnings development, investors order the options as inertia, delegation, and active management.

\section{Sensitivity Analysis and Welfare Gains from Access to Financial Advice 6.1 Examining the Impact of Learning by Doing}

To more clearly illustrate the importance of learning by doing in our model, we next conduct a sensitivity analysis by building and solving a model without the learning by doing mechanism used in our base case above. To do so, we restate the human capital function as follows:

$$
H_{t+1}=\left(\left(1-\delta_{0}-\delta_{1} t\right) H_{t}+a_{0}+a_{1} t+a_{2} t^{2}\right) \lambda
$$

The experience accumulation part $F_{t}\left(l_{t}, H_{t}\right)$ in our original human capital accumulation process is now replaced by a deterministic function of age with parameters $\left(a_{0}, a_{1}, a_{2}\right)$. We then re-estimate parameters of this new human capital process $\left(\delta_{0}, \delta_{1}, a_{0}, a_{1}, a_{2}, \lambda\right)$ along with parameters of wage rate shocks (transitory and permanent wage shock) by matching the model's moment conditions with the moments of empirically-observed wage profiles of male high school graduates derived using the PSID (Hubener et al. 2013). ${ }^{29}$

${ }^{29}$ The estimated values are $-0.0125\left(\delta_{0}\right),-0.00012542\left(\delta_{1}\right), 0.0011\left(\mathrm{a}_{0}\right),-0.0080\left(\mathrm{a}_{1}\right), 0.000081419\left(\mathrm{a}_{2}\right), 6.49 \%(\lambda)$, 
Having turned off learning by doing, we next re-solve the model and compare results with our benchmark case (see Table 9). Before discussing findings, it is useful to note that there are two competing forces driving inertia when there is no learning by doing. The first is the reduced opportunity cost of active management which boosts active management (i.e., decreases inertia): an investor managing his own assets must sacrifice only current leisure time or earnings, but not future human capital. The second results from the reduced attractiveness of work given that employment no longer enhances future wages. This reduces labor supply and earnings as well as wealth, which in turn makes active management less profitable; the result is to discourage active management (i.e., increase inertia).

\section{Table 9 here}

Column 2 of Table 9 show that the latter effect dominates, with an overall increase in inertia. Compared to the baseline (Column 1), the inertia fraction rises, on average, by $12.1 \%$, $11.3 \%$, and $9.7 \%$ for ages $20-45,45-60$, and 65+, respectively. Additionally, labor supply falls by about 39\% for those age 20-45 and 23\% for those age 45-60. As anticipated, young investors respond to the attractiveness of future labor market prospect more sensitively.

\subsection{The Impact of the Initial Stock Market Participation Cost}

Next we extend our model to include a fixed initial cost of stock market participation (as in Cocco 2005, Gomes and Michaelides 2005). Because our model already has a stock account balance $\left(Z_{t}\right)$ as a state variable, we can define initial stock market participation as the case when the investor's current period's stock balance $\left(Z_{t}\right)$ is zero, but his chosen stock investment $\left(S_{t}\right)$ out of savings is positive. This permits us to avoid creating an additional state variable. ${ }^{30}$

30.78\% (transitory wage shock), 6.87\% (permanent wage shock).

${ }^{30}$ This specification cannot rule out the possibility that an investor would need to incur participation costs again when he returns to stock market after liquidating his entire equity position. However our simulation results show that 
We model the fixed market participation cost as a fraction of the permanent wage shock (as in Gomes and Michaelides 2005). Given an initial fixed cost of stock market participation, wealth evolves as follows:

$$
W_{t+1}=S_{t} R_{t+1}+\left(W_{t}-C_{t}-S_{t}\right) \bar{R}+E_{t+1}-F \times Y_{i, t} \times I_{i, t}
$$

where $Y_{i, t}$ is a permanent wage shock and $I_{i, t}$ is an indicator variable for initial stock market participation having 1 when $Z_{t}=0$ and $S_{t}>0$. As in Gomes and Michaelides (2005), the fixed cost $F$ is set at $2.5 \%$ of the permanent wage shock. Column 3 of Table 9 presents the result of portfolio management methods with initial participation cost. The new solution shows that overall pattern of inertia over the life cycle is same as before and the proportion of inertia managers increases only marginally in the early years. In the first 20 years, initial participation costs increases inertia only by $1.8 \%$; after that the impact becomes minimal. In other words, an initial participation cost cannot fully explain observed inertia patterns in the data.

We also conduct a test to determine whether the U-shaped time cost is responsible for the the U-shaped pattern of inertia over the life cycle. Our analysis shows that this is not the case. For instance, when we set the time cost at 3\% for all ages, column 4 of Table 9 shows that $70 \%$ of young investors (age 20-35) choose inertia, 49\% of middle-aged investors (ages 50-65), 40\% of early retirees (age 65-80), and $55 \%$ of old investors (age 80+). The ratio of inertia investors is slightly lower for the youngest and oldest investors, compared to the baseline case, but the U-shaped pattern is still clearly evident.

Column 5 of Table 9 presents a sensitivity analysis for college graduates, to evaluate how wage/age profiles influences results. We re-estimate parameters of the human capital process with the observed wage trend for college graduates in the PSID and re-solve the model. 
Compared to the baseline case of high school graduates, college graduates earn higher labor income, have higher wealth, work more, and invest more in equity. Compared to the baseline case, the inertia level for college grads is modestly less than for the high school educated: 73\% vs $76 \%$ for ages $20-35$, $46 \%$ vs. $50 \%$ for ages $50-65$, and $40 \%$ vs. $44 \%$ for ages $80+$ ). The U-shaped pattern of inertia again persists.

\subsection{Welfare Analysis of a Delegation Option and Sensitivity Analysis}

To assess how consumers value access to a delegation option, we next compare donsumer welfare in a delegation regime versus that in a no-delegation world. We measure this in terms of a certainty equivalent (CE) consumption stream change, or the stream of consumption that would afford the investor the same level of expected lifetime utility if he lacked access to the delegation option, versus having it (Cocco et al. 2005). ${ }^{31}$ Table 10, Panel A, shows for our baseline specification (Column 1) that providing investors with access to a financial advisor increases lifetime welfare by the equivalent of a $1.2 \%$ enhancement in their annual consumption streams. This is similar in magnitude to that reported in Cocco et al. (2005), who compared welfare levels in two worlds, one with a fixed and the other with a flexible equity share.

\section{Table 10 here}

We also conduct a sensitivity analysis for different costs of financial advice, to evaluate investors' potential welfare gains from lowering entry barriers to financial advisory services. As noted above, current industry practice is to set a minimum fixed fee commensurate with a

31 The certainty equivalent constant consumption stream $\left(c_{C E}\right)$ is defined as:

$$
V_{1}\left(W_{1}, H_{1}, Z_{1}, y_{1}\right)=E\left[\sum_{t=0}^{T} \beta^{t}\left(\prod_{i=0}^{t} p_{i}\right) \frac{1}{1-\gamma}\left(C_{t}\left(L_{t}\right)^{\alpha}\right)^{1-\gamma}\right]=\sum_{t=0}^{T} \beta^{t}\left(\prod_{i=0}^{t} p_{i}\right) \frac{1}{1-\gamma}\left(C_{C E}\left(L_{*}\right)^{\alpha}\right)^{1-\gamma}
$$

where $L_{*}$ is a fixed level of leisure and $\left(X_{1}, H_{1}, Z_{1}, y_{1}\right)$ is a pair of state variables. With some algebraic manipulation, we get:

$$
C_{C E}=\left[\frac{(1-\gamma) V_{1}}{\sum_{t=0}^{T} \beta^{t}\left(\prod_{i=0}^{t} p_{i}\right)\left(L_{*}^{\alpha}\right)^{1-\gamma}}\right]^{\frac{1}{1-\gamma}}
$$

In calculating this measure, we set leisure $L_{*}$ as time deducted from mean labor hours over working years. 
required minimum asset balance of about $\$ 240,000$, which is high compared to average investors' asset levels. Column 2 of Panel A shows that eliminating the minimum fee for advisory services would raise welfare by $1.43 \%$, compared to the case where no delegation is available. This welfare improvement results from the fact that less-wealthy investors gain access to cheapter financial advice, allowing them to use their time for leisure or work. Column 2 of Panel B shows that, compared to the baseline case, eliminating the minimum fee leads younger investors (age 20-35) to increase their usage of a financial advisor by $15 \%$ percentage points, and in retirement, financial advice utilization rises by about $8 \%$. At the same time, both inertia and active management decline. Conversely, as seen in Column 3, Panel A, a higher minimum fee commensurate with the industry’s average required minimum balance of around $\$ 250,000$ cuts the welfare gains by about 20\%, compared to the case of no minimum fee (Column 2). In Panel B, Column 3, we see that very few people, mainly those at the top of the wealth distribution, access the servce at this higher cost. Only about 1.8\% of young investors (aged 20 35) select the delegation option and during retirement, only about $15 \%$ seek financial advice. ${ }^{32}$ Compared to the no minimum fee case (Column 2), a higher minimum fee induces the young (age 20-35) and older (age 65+) investors to choose more inertia than middle-aged investors. In this case, when portfolio adjustment becomes necessary, most people find it optimal to manage their money themselves (i.e., actively manage), rather than to pay the high advisory fee (i.e., delegation). In other words, lowering the entry barrier to financial advisory services can help people of all ages (especially the young and the old) manage their financial assets optimally, and thereby save their scarcest resource, time for accumulating more job-specific skills or enjoying leisure.

\footnotetext{
${ }^{32}$ With this level of minium fee, retirees (aged +65) become the main customer group.
} 


\section{Conclusion}

Though individuals are increasingly expected to manage their own finances with ever-more complex financial products, most people in fact exhibit investor inertia, devoting only sparse attention to their financial portfolios and fail to actively manage their finances. To understand what might seem to be puzzling behavior, we build and solve a realistically-calibrated life cycle model where the time cost required to manage one's portfolio is traded off with the opporutnity to accumulate job-specific knowledge. Using reasonable parameters, we show that our model implies sensible patterns of portfolio inertia across age groups. Investors who can accumulate job-specific knowledge by working tend to devote less time to managing their money when young. Middle-age individuals have more assets to invest and suffer less from the opportunity costs of active portfolio management, though many still elect inertia. Declining decision making efficiency and rising mortality risk later in life prompts many older investors to elect portfolio inertia. When investors can delegate portfolio management to a financial advisor, this enables many to avoid portfolio inertia. In general, our model predicts that younger and older investors will find financial advisors most attractive. Finally, we find important welfare gains result from having a delegation option.

This research contributes to a growing body of research on decision making over the life cycle, $^{33}$ an area of substantial policy interest in the wake of the global financial crisis. In the US for instance, the White House recently convened a multi-agency meeting of behavioral economists and psychologists to better understand how decision making changes with age (NIA 2013). Our work adds to the discussion by developing and simulating a life cycle model to illustrate optimal portfolio management methods selected by finitely-lived investors who face

\footnotetext{
33 For instance, see Agarwal et al. (2009); Korniotis and Kumar (2011); and Samanez-Larkin and Knutson (2014).
} 
portfolio management costs and an age-dependent inefficiency pattern for financial decision making.

One topic we do not take up here is the possibility of a conflict of interest between an investor seeking to maximize his utility, and his financial advisor seeking to maximize his own income. ${ }^{34}$ For example, if an advisor's compensation is commission-based, he may be more likely to encourage return-chasing or high-fee actively managed mutual funds (Mullainathan et al. 2012). The present paper considers only fee-based advice, which is less susceptible to such conflicts, but future work could consider the potential for moral hazard if investors are uninfomed. Additional extensions might also extend our model with parameter uncertainty and learning (Brennan 1998; Xia 2001). Nevertheless our key insight linking job-specific human capital and portfolio inertia will still be relevant, as long as a time cost of financial management has negative consequences for labor market earnings.

Our findings should be of interest to a variety of stakeholders including individual investors, financial advisors, retirement plan sponsors, and policymakers. In particular, we show that those who most value financial advisory services are the young and the older age groups, so making such services available can enhance their well-being. Also of interest is the prediction that some middle-aged clients will wish to continue actively manage their own financial assets, even when a delegation option is available. Policymakers could do more to enhance welfare gains by improving investor access to financial advisory services. When financial advisors with fiduciary responsibility can help investors manage their financial wealth optimally, this will enable more people to accrue job-specific skills, thus contributing to the economy as a whole.

\footnotetext{
34 See for instance Bergstresser et al. (2009), Hackethal et al. (2012) and Stoughton et al. (2011).
} 


\section{References}

Abel, A., Eberly, J.C., Panageas, S., 2013. Optimal Inattention to the Stock Market with Information Costs and Transaction Costs. Econometrica 81: 1455-1481.

Adda, J., Cooper, R.W., 2000. Balladurette and Juppette: A Discrete Analysis of Scrapping Subsidies. Journal of Political Economy, 108 (4), 778-806.

Agarwal, S., Driscoll, J.C., Gabaix, X., Laibson, D., 2009. The Age of Reason: Financial Decisions over the Life-Cycle with Implications for Regulation. Brookings Papers on Economic Activity 40, 51-117.

Ameriks, J., Zeldes. S.P., 2004. How Do Household Portfolio Shares Vary With Age? Working Paper, Columbia University GSB.

Anagol, S., Kim, H.H., 2012. The Impact of Shrouded Fees: Evidence from a Natural Experiment in the Indian Mutual Funds Market. American Economic Review 102(1), 576-593.

Arrow, K. J., 1962. The Economic Implications of Learning by Doing. Review of Economic Studies 29, 155-173.

Barber, B.M., Odean, T., 2000. Trading is Hazardous to your Wealth: The Common Stock Investment Performance of Individual Investors. Journal of Finance 55, 773-806.

Battistin, E., A. Brugiavini, E. Rettore, Weber, G., 2009. The Retirement Consumption Puzzle: Evidence from a Regression Discontinuity Approach. American Economic Review 99 (5), 2209-2226.

Becker, G., 1964. Human Capital. Chicago: The University of Chicago Press.

Bell, F.C., Miller, M.L., 2012. Life Tables for the US Social Security Area 1900-2010. OACT Actuarial Study No. 120. http://www.ssa.gov/oact/NOTES/as120/LifeTables_Body.html

Ben-Porath, Y., 1967. The Production of Human Capital and the Life Cycle of Earnings. Journal of Political Economy 75, 352 - 365.

Bergstresser, D., Chalmers, J.M.R, Tufano, P., 2009. Assessing the Costs and Benefits of Brokers in the Mutual Fund Industry. Review of Financial Studies 22, 4129-4156.

Bilias, Y., Georgarakos, D., Haliassos, M., 2009. Portfolio Inertia and Stock Market Fluctuations. Journal of Money, Credit, and Banking 42, 715-742.

Bodie, Z., Merton, R.C., Samuelson, W.F., 1992. Labor Supply Flexibility and Portfolio Choice in a Life Cycle Model. Journal of Economic Dynamics and Control 16, 427-449.

Bonaparte, Y., Cooper, R., 2009. Costly Portfolio Adjustment. National Bureau of Economic Research Working Paper 15227.

Brandt, M.W., Goyal, A., Santa-Clara, P., Stroud, J.R., 2005. A Simulation Approach to Dynamic Portfolio Choice with an Application to Learning about Return Predictability. Review of Financial Studies 18, 831-873.

Brennan, M., 1998. The Role of Learning in Dynamic Portfolio Decisions. European Finance Review 1, 295-306.

Brunnermeier, M.K., Nagel, S., 2008. Do Wealth Fluctuations Generate Time-Varying Risk Aversion? Micro-Evidence on Individuals' Asset Allocation. American Economic Review 98, 713-736. 
Bureau of Labor Statistics (BLS), 2012. American Time Use Survey. US Department of Labor. http://www.bls.gov/tus/

Calvet, L.E., Campbell, J.Y., Sodini, P., 2009a. Fight or Flight? Portfolio Rebalancing by Individual Investors. Quarterly Journal of Economics 124 (1), 301-348.

Calvet, L.E., Campbell, J.Y., Sodini, P., 2009b. Measuring the Financial Sophistication of Households. American Economic Review 99, 393-398.

Campanale, C., Fugazza, C., Gomes, F., 2014. Life-Cycle Portfolio Choice with Liquid and Illiquid Financial Assets. Journal of Monetary Economics 2014, in press.

Campbell, J. Y., Jackson, H.E., Madrian B.C., Tufano, P., 2011. Consumer Financial Protection. Journal of Economic Perspectives 25(1), 91-114.

Carlin, B.I., 2009, Strategic Price Complexity in Retail Financial Markets. Journal of Financial Economics 91, 278-287.

Carlin, B. I., Manso, G., 2011, Obfuscation, Learning, and the Evolution of Investor Sophistication, Review of Financial Studies 24, 754-785.

Chai, J., Horneff, W., Maurer, R., Mitchell, O.S., 2011. Optimal Portfolio Choice over the Life-Cycle with Flexible Work, Endogenous Retirement, and Lifetime Payouts. Review of Finance 15, 875-907.

Choi, J., Laibson, D., Madrian, B., Metrick, A., 2002. Defined Contribution Pension: Plan Rules, Participant Decisions, and the Path of Least Resistance, in Tax Policy and the Economy 16, James M. Poterba, ed. (Cambridge, MA: MIT Press).

Cocco, J. F., Gomes, F. J., Maenhout, P. J., 2005. Consumption and Portfolio Choice over the Life Cycle. Review of Financial Studies 18, 491-533.

Cocco, J. F., Gomes, F.J., 2012. Longevity Risk, Retirement Savings, and Financial Innovation. Journal of Financial Economics 103, 507-529.

Chiang, Y., Hirshleifer, D., Qian, Y., Sherman, AE., 2011. Do Investors Learn from Experience? Evidence from Frequent IPO Investors. Review of Financial Studies 24, 1560-1589.

Christelis, D., Jappelli, T., Padula, M., 2010. Cognitive Abilities and Portfolio Choice. European Economic Review 54, 18-38

Dahlquist M., Martinez, J.V., 2015. Investor Inattention: A Hidden Cost of Choice in Pension Plans? European Financial Management 21, 1-19.

Dellavigna S., Pollet J., 2009. Investor Inattention and Friday Earnings Announcements. Journal of Finance 64, 709-749.

Economist. 2011. Over to You: Special Report on Pensions. April.

Frazzini, A., Lamont, O.A., 2008. Dumb Money: Mutual Fund Flows and the Cross-section of Stock Returns. Journal of Financial Economics 88, 299-322.

Gamble, K.J., Boyle, P.A., Yu, L., Bennett, D.A., 2014. Aging and Financial Decision Making. Management Science. Forthcoming (published online in Articles in Advance, October 29). 
Gomes, F., Michaelides, A., 2005. Optimal Life-Cycle Asset Allocation: Understanding the Empirical Evidence. Journal of Finance 60, 869-904.

Gomes, F. J., Kotlikoff, L. J., Viceira, L.M., 2008. Optimal Life-Cycle Investing with Flexible Labor Supply: A Welfare Analysis of Life-Cycle Funds. American Economic Review 98, 297-303.

Hackethal, A., Halliassos, M., Jappelli, T., 2012. Financial Advisors: A Case of Babysitters? Journal of Banking and Finance 36, 509-524.

Gomes J.L., Cattell R.B., 1967. Age Differences in Fluid and Crystalized Intelligence. Acta Psychologica, 26, 107-129.

Horneff, W.J., Maurer, R., Mitchell, O.S., Stamos, M.Z., 2009. Asset Allocation and Location over the Life Cycle with Investment-linked Survival-contingent Payouts. Journal of Banking \& Finance 33, 1688-1699.

Hubener, A., Maurer, R., Mitchell, O.S., 2013. How Family Status and Social Security Claiming Options Shape Optimal Life Cycle Portfolios. NBER WP19583.

Johnson, S., Kotlikoff, L.J., Samuelson, W., 2001. Can People Compute? An Experimental Test of the Life Cycle Consumption Model. In Kotlikoff, L. J. (ed.). Essays on Saving, Bequests, Altruism, and Life-Cycle Planning. MIT Press, 335-386.

Korniotis, G.M., Kumar, A., 2011. Do Older Investors Make Better Investment Decisions? The Review of Economics and Statistics 93, 244-265.

Levitt, D. S., List, J.A., Syverson C., 2013. Toward an Understanding of Learning by Doing: Evidence from an Automobile Assembly Plant. Journal of Political Economy 121, 643-681.

Love, A.D., 2010. The Effects of Marital Status and Children on Savings and Portfolio Choice. Review of Financial Studies 23, 385-432.

Low, H., 2005. Self-insurance in a Life-cycle Model of Labor Supply and Savings. Review of Economic Dynamics 8, 945-975.

Lucas, R.E., Jr., 1988. On the Mechanics of Economic Development. Journal of Monetary Economics 22 (1), 3-42.

Lusardi, A., Mitchell, O.S., 2007. Baby Boomer Retirement Security: The Roles of Planning, Financial Literacy, and Housing Wealth. Journal of Monetary Economics 54, 205-224.

Lusardi, A., Mitchell, O.S., 2014. The Economic Importance of Financial Literacy: Theory and Evidence. Journal of Economic Literature 52, 5-44.

Madrian, B., Shea, D., 2001. The Power of Suggestion: Inertia in 401(k) Participation and Savings Behavior. Quarterly Journal of Economics 116, 1149-1188.

Merton, R.C., 1971. Optimum Consumption and Portfolio Rules in a Continuous-Time Model. Journal of Economic Theory 3, 373-413.

Mitchell, O.S., Mottola, G. R., Utkus, S. P., Yamaguchi, T., 2006. The Inattentive Participant: Portfolio Trading Behavior in 401(k) Plans. Michigan Retirement Research Center Working Paper. 
Mitchell, O.S., Mottola, G.R., Utkus, S.P., Yamaguchi, T., 2009. Default, Framing and Spillover Effects: The Case of Life Cycle Funds in 401(k) Plans. NBER WP15108.

Mitchell, O.S., Smetters, K., 2013. The Market for Financial Advice. Oxford: Oxford University Press.

Mullainathan, S., Noeth, M., Schoar, A., 2012. The Market for Financial Advice: An Audit Study. NBER WP 17929.

National Institute on Aging (NIA), 2013. Meeting Summary: Psychological Science and Behavioral Economics in the Service of Public Policy. http://www.nia.nih.gov/sites/default/files/psychological_science_and_behavioral_economics.pdf

Ou-Yang, H., 2003. Optimal Contracts in a Continuous-Time Delegated Portfolio Management Problem. Review of Financial Studies 16, 173-208.

Samanez-Larkin, G.R., Knutson, B., 2014. Reward Processing and Risky Decision Making in the Aging Brain. In V.F. Reyna \& V. Zayas (Eds.) The Neuroscience of Risky Decision Madrian,

Sharpe, W. F., 1985. Decentralized Investment Management. Journal of Finance 36, 423-442.

Stoughton, N., Wu, Y., Zechner, J., 2011. Intermediated Investment Management. Journal of Finance 66, 947-980

Tang, N., Mitchell, O.S., Mottola, G.R., Utkus, S.P., 2010. The Efficiency of Sponsor and Participant Portfolio Choices in 401(k) Plans. Journal of Public Economics 94, 1073-1085.

U.S. Census Bureau, 2012. The 2012 Statistical Abstract. Table 1211 Stock Ownership by Age of Head of Family and Family Income: 2001 to 2007. http://www.census.gov/compendia/statab/cats/banking_finance_insurance/stocks_and_bo nds_equity_ownership.html

U.S. Security and Exchange Commission. 2008. Mandatory Disclosure Documents Telephone Survey. http://www.sec.gov/pdf/disclosuredocs.pdf.

Van Rooij, M., Lusardi, A., Alessie, R., 2011. Financial Literacy and Stock Market Participation. Journal of Financial Economics, 101, 449-472.

Vissing-Jorgensen, A., 2003. Perspectives on Behavioral Finance: Does ’Irrationality’ Disappear with Wealth? Evidence from Expectations and Actions. In M. Gertler and K. Rogoff (eds.) NBER Macroeconomics Annual. 18, 139-194.

Xia, Y., 2001. Learning about Predictability: The Effects of Parameter Uncertainty on Dynamic Asset Allocation Journal of Finance 56, 205-246. 
Table 1: Parameter Values for Numerical Solution of Baseline Model

\begin{tabular}{|c|c|}
\hline Parameter & Baseline Value \\
\hline Working periods & 45 \\
\hline Retirement periods & 35 \\
\hline Time discounting $\beta$ & 0.96 \\
\hline Risk aversion $\gamma$ & 3 \\
\hline Leisure preference $\alpha$ & 1.0 \\
\hline Experience formulation $a$ & 0.0462 \\
\hline Elasticity of $H_{t}$ accumulation $\theta$ & 0.7596 \\
\hline Depreciation of Human Capital $\delta_{t}$ & $0.16 \%+0.023595 \times$ year \\
\hline Inefficiency of financial decision making $\phi_{t}$ & $\frac{0.09-0.03}{30^{4}}(t-30)^{4}+0.03$ \\
\hline Std. dev. of permanent wage shock & 0.0710 \\
\hline Std. dev. of human capital shock & 0.0434 \\
\hline Std. dev. of transitory wage shock (pre-retirement) & 0.1726 \\
\hline $\begin{array}{l}\text { Std. dev. of transitory earnings shock } \\
\text { (post-retirement) }\end{array}$ & 0.28 \\
\hline Replacement rate & $20 \%$ of maximum earnings at age 65 \\
\hline Risk premium & 0.04 \\
\hline Std. dev. of stock return $\sigma_{\text {stock }}$ & 0.205 \\
\hline Risk free rate $R_{f}$ & 1.01 \\
\hline Delegation annual fee: variable rate $\varphi_{p t g}$ & 1. $41 \%$ per annum \\
\hline $\begin{array}{l}\text { Delegation annual fee: fixed fee } \varphi_{\min }(1.41 \% \text { of } \\
\text { min. req'd balance of } \$ 150,000)\end{array}$ & $\$ 2,115$ \\
\hline Correlation between wage and stock return $\sigma_{\epsilon S}$ & 0.0 \\
\hline Initial wealth for simulation $W_{0}$ & 0 \\
\hline Initial human capital for simulation $H_{0}$ & 10 \\
\hline Initial stock balance for simulation $\mathrm{Z}_{0}$ & 0 \\
\hline Initial wage shock for simulation $y_{0}$ & 0.1 \\
\hline
\end{tabular}

Notes: This table summarizes our baseline model parameter settings. 
Table 2: Portfolio Inertia and Stock Trading Behavior over the Life Cycle

\begin{tabular}{|c|c|c|c|c|c|c|}
\hline \multirow[b]{3}{*}{ Age } & \multicolumn{3}{|c|}{ Total Wealth $<\$ 150,000$} & \multicolumn{3}{|c|}{ Total Wealth $\geq \$ 150,000$} \\
\hline & \multirow{2}{*}{$\begin{array}{c}\text { Inertia } \\
\text { No Trade }\end{array}$} & \multicolumn{2}{|c|}{ Active Management } & \multirow{2}{*}{$\begin{array}{c}\text { Inertia } \\
\text { No Trade }\end{array}$} & \multicolumn{2}{|c|}{ Active Management } \\
\hline & & Bought & Sold & & Bought & Sold \\
\hline $20-35$ & 0.783 & 0.156 & 0.061 & 0.133 & 0.623 & 0.244 \\
\hline $36-50$ & 0.665 & 0.143 & 0.192 & 0.202 & 0.426 & 0.372 \\
\hline $51-65$ & 0.750 & 0.108 & 0.142 & 0.164 & 0.386 & 0.450 \\
\hline $66+$ & 0.755 & 0.101 & 0.143 & 0.029 & 0.382 & 0.589 \\
\hline
\end{tabular}

Notes: This table shows the proportion of investors by total wealth and age who exhibited inertia (i.e., no stock purchase), purchased additional stock, or sold stock. Results tabulated from 2,000 independent simulation runs of base case model without a delegation option. The cut-off point for total wealth (see equation 8) is based on the medium level of wealth for middle-aged investors. 
Table 3: Dynamics of Portfolio Management over the Life Cycle with No Delegation Option

\begin{tabular}{lcccccc}
\hline & Mean & Std & Median & $5 \%-\mathrm{Q}$ & $95 \%-\mathrm{Q}$ & $\mathrm{N}$ \\
\hline No. of switches & 11.55 & 7.02 & 12.00 & 0.00 & 22.00 & 2,000 \\
Years of inertia & 45.97 & 25.00 & 42.00 & 13.00 & 80.00 & 2,000 \\
Years of active mgmt & 34.03 & 25.00 & 38.00 & 0.00 & 67.00 & 2,000 \\
First year of active mgmt & 8.95 & 8.23 & 7.00 & 4.00 & 24.00 & 1,767 \\
\hline
\end{tabular}

Notes: Results tabulated from 2,000 simulation runs of base case model. No. of switches refers to the number of times someone changed portfolio management method (from active-managed to inertia or vice versa) between age 20 and 100, conditional on survival. Years of inertia refers to the total length of the inertia period for specific simulated life cycle paths, and years of active mgmt refers to the total length of the active management period over specific simulated life cycle paths. First year of active mgmt refers to the first year when an individual changes from inertia to active management. Some people never elect active management and remain inactive throughout their entire lifetimes which is why the total number of observations of first year of active mgmt is less than the total number of simulations.

Table 4: Dynamics of Portfolio Management over the Life Cycle with a Delegation Option

\begin{tabular}{lcccccc}
\hline & Mean & Std & Median & $5 \%-\mathrm{Q}$ & $95 \%-\mathrm{Q}$ & $\mathrm{N}$ \\
\hline No of switches & 18.82 & 10.74 & 22.00 & 0.00 & 33.00 & 2,000 \\
Years of inertia & 44.94 & 25.49 & 40.00 & 11.00 & 80.00 & 2,000 \\
Years of active mgmt & 17.69 & 11.42 & 20.00 & 0.00 & 34.00 & 2,000 \\
Years of delegation & 17.36 & 15.93 & 15.00 & 0.00 & 42.00 & 2,000 \\
First year change & 8.39 & 7.94 & 6.00 & 4.00 & 21.00 & 1,778 \\
$\quad$ First year active mgmt & 14.31 & 8.44 & 13.00 & 7.00 & 26.00 & 1,776 \\
$\quad$ First year delegation & 9.26 & 10.35 & 6.00 & 4.00 & 29.00 & 1,581 \\
\hline
\end{tabular}

Notes: For definitions, see Table 3. Also Years of delegation refers to the length of the delegated management period for the specified simulated life cycle paths. First year delegation refers to the first year when people change to delegation from inertia or from active management. Results tabulated from 2,000 simulation runs of base case model. Some people never elect active management or delegation which is why the total number of observations of first year of active mgmt and first year delegation is less than the total number of simulations. 
Table 5: Portfolio Management Transitions and Equity Choice Over the Life Cycle: With a Delegation Option

A. Choice of Portfolio Management Method by Age (\%)

\begin{tabular}{lcccccc}
\hline Age & $20-35$ & $36-50$ & $50-65$ & $65-80$ & $80+$ & Total \\
\hline Inertia & 73.39 & 50.87 & 49.3 & 44.43 & 61.22 & 56.18 \\
Active mgmt & 7.87 & 28.68 & 29.89 & 48.34 & 2.38 & 22.12 \\
Delegation & 18.73 & 20.45 & 20.81 & 7.23 & 36.39 & 21.7 \\
\hline
\end{tabular}

B. Portfolio Management Transitions by Age, with a Delegation Option (\%)

\begin{tabular}{lcccccc}
\hline Age & $20-35$ & $36-50$ & $50-65$ & $65-80$ & $80+$ & Total \\
\hline $\begin{array}{l}\text { Inertia to: } \\
\quad \text { Inertia }\end{array}$ & 70.96 & 44.06 & 43.14 & 41.86 & 59.09 & 52.28 \\
$\quad$ Active mgmt & 1.45 & 4.87 & 4.35 & 2.25 & 0.14 & 2.46 \\
$\quad$ Delegation & 3.62 & 2.71 & 2.5 & 0.33 & 4.06 & 2.73 \\
Active management to: & & & & & & \\
$\quad$ Inertia & 2.43 & 6.81 & 6.16 & 2.57 & 2.14 & 3.9 \\
$\quad$ Active mgmt & 6.42 & 23.8 & 25.54 & 46.09 & 2.24 & 19.66 \\
$\quad$ Delegation & 15.11 & 17.74 & 18.31 & 6.9 & 32.34 & 18.97 \\
\hline
\end{tabular}

C. Equity Fraction out of Savings by Age (\%)

\begin{tabular}{lcccccc}
\hline Age & $20-35$ & $36-50$ & $50-65$ & $65-80$ & $80+$ & Total \\
\hline Inertia & 0.333 & 0.622 & 0.572 & 0.482 & 0.483 & 0.484 \\
Active mgmt & 0.913 & 0.819 & 0.714 & 0.563 & 0.370 & 0.682 \\
Delegation & 0.743 & 0.715 & 0.653 & 0.461 & 0.371 & 0.548 \\
\hline Total & 0.456 & 0.698 & 0.631 & 0.519 & 0.440 & 0.542 \\
\hline
\end{tabular}

Notes: This table illustrates life cycle patterns of portfolio management methods and equity share when delegation is feasible. Panel A shows the fraction of investors selecting inertia, active management, or delegation by age. Panel $\mathrm{B}$ traces trasitions across portfolio management methods, given a delegation option. Panel $\mathrm{C}$ depicts the average fraction of saving invested in equities depending on whether the investor elects inertia, active management, or delegation. Savings is the total wealth minus consumption. Averages are generated from 2,000 independent simulations for individuals based on optimal feedback controls from the baseline specification of the life cycle model. 
Table 6: Change in Key Variables: With vs. Without a Delegation Option (\%)

\begin{tabular}{lccccccc}
\hline Age & $\begin{array}{c}\text { Total } \\
\text { Wealth }\end{array}$ & $\begin{array}{c}\text { Equity } \\
\text { Share }\end{array}$ & $\begin{array}{c}\text { Labor } \\
\text { Income }\end{array}$ & $\begin{array}{c}\text { Consump- } \\
\text { tion }\end{array}$ & $\begin{array}{c}\text { Labor } \\
\text { Supply }\end{array}$ & $\begin{array}{c}\text { Human } \\
\text { Capital }\end{array}$ & Leisure \\
\hline $20-35$ & 1.68 & 1.68 & 5.78 & 4.22 & 5.44 & 0.04 & 2.09 \\
$36-50$ & 1.49 & 1.56 & 10.59 & 9.24 & 9.07 & 0.10 & 3.49 \\
$51-65$ & 0.89 & 2.14 & 11.74 & 12.79 & 9.69 & 0.10 & 3.73 \\
$66+$ & 0.56 & 1.21 & - & 0.18 & - & - & 6.69 \\
\hline
\end{tabular}

Notes: The numbers represent the percentage increase in key variables for all individuals summed over those in the age group having access to a delegation option versus not having access to a delegation option. Equity share is a fraction of equity investment in savings $\left(S_{t} /\left(S_{t}+B_{t}\right)\right)$. Averages for total wealth are value-weighted. See text.

Table 7: Factors Associated with Portfolio Inertia (versus Active Management) with No Delegation Option: Marginal Effects from Descriptive Logit Analysis

\begin{tabular}{llll}
\hline & \multicolumn{3}{c}{ Inertia Chosen (vs Active Management) } \\
& $(1)$ & $(2)$ & $(3)$ \\
\hline Wealth $_{\{-1\}}$ & $-2.568^{* * *}$ & & $-2.571^{* * *}$ \\
& $(0.01)$ & & $(0.01)$ \\
Stock market shock & $\{-1\}$ & & $-0.083^{* *}$ \\
& & $-0.077^{* * *}$ & $(0.04)$ \\
Wage shock $_{\{-1\}}$ & $(0.02)$ & $1.009^{* * *}$ \\
& & $0.474^{* * *}$ & $(0.09)$ \\
\hline
\end{tabular}

Notes: Each column reports the estimated impact of variables from separate Logit regressions, where the dependent variable $=1$ if the individual elected inertia in that period, or $0=$ active management. The fraction of observations experiencing inertia totaled $57.47 \%$ and active management $42.53 \%$. Standard errors in parentheses. *, **, and *** indicate statistical significance at $10 \%, 5 \%$, and $1 \%$ respectively. See text. 
Table 8: Factors Associated with Portfolio Inertia and Delegation (versus Inertia) with a Delegation Option: Marginal Effects from Descriptive Multinomial Logit Analysis

A. Reference Group = Active Management

\begin{tabular}{|c|c|c|c|}
\hline & \multicolumn{3}{|c|}{ Inertia Chosen (vs Active Management) } \\
\hline & (1) & $(2)$ & (3) \\
\hline \multirow[t]{2}{*}{ Wealth $_{\{-1\}}$} & $-2.499 * * *$ & & $-2.488 * * *$ \\
\hline & $(0.05)$ & & $(0.05)$ \\
\hline \multirow[t]{2}{*}{ Stock market shock $\{-1\}$} & & $-0.218 * *$ & $-0.398 * * *$ \\
\hline & & (0.09) & $(0.11)$ \\
\hline \multirow[t]{4}{*}{ Wage shock $k_{\{-1\}}$} & & $2.654 * * *$ & $1.627^{* * *}$ \\
\hline & & $(0.24)$ & $(0.27)$ \\
\hline & \multicolumn{3}{|c|}{ Delegation Chosen (vs Active Management) } \\
\hline & (1) & $(2)$ & (3) \\
\hline \multirow[t]{2}{*}{ Wealth $_{\{-1\}}$} & $-0.743 * * *$ & & $-0.744 * * *$ \\
\hline & $(0.03)$ & & $(0.03)$ \\
\hline \multirow[t]{2}{*}{ Stock market shock $k_{\{-1\}}$} & & $-0.242 * *$ & $-0.371 * * *$ \\
\hline & & $(0.10)$ & $(0.10)$ \\
\hline \multirow[t]{2}{*}{ Wage shock $k_{\{-1\}}$} & & $0.929 * * *$ & $0.556 * *$ \\
\hline & & $(0.24)$ & $(0.25)$ \\
\hline
\end{tabular}

B. Reference Group = Inertia

\begin{tabular}{|c|c|c|c|}
\hline \multirow[b]{2}{*}{ Wealth $_{\{-1\}}$} & \multicolumn{3}{|c|}{ Delegation Chosen (vs Inertia) } \\
\hline & $\begin{array}{l}1.756^{* * *} \\
(0.04)\end{array}$ & & $\begin{array}{l}1.744^{* * *} \\
(0.04)\end{array}$ \\
\hline Stock market shock $_{\{-1\}}$ & & $\begin{array}{l}-0.024 \\
(0.10)\end{array}$ & $\begin{array}{l}0.027 \\
(0.11)\end{array}$ \\
\hline Wage shock $k_{\{-1\}}$ & & $\begin{array}{l}-1.725^{* * *} \\
(0.25)\end{array}$ & $\begin{array}{l}-1.071^{* * *} \\
(0.27)\end{array}$ \\
\hline
\end{tabular}

Notes: Each column reports the estimated impact of variables from separate Multinomial Logit regressions where the dependent variable: $0=$ inertia, $1=$ active, and $2=$ delegation. Individual fixed effects are controlled. Observations of active management account for $22.13 \%$ of the sample; inertia for $55.54 \%$; and $22.33 \%$ for delegation respectively. Standard errors in parentheses. *, **, and *** indicate statistical significance at $10 \%, 5 \%$, and $1 \%$ respectively. See text. 
Table 9: Sensitivity Analysis: Change in Portfolio Management Method with No Delegation Option (in percentage points)

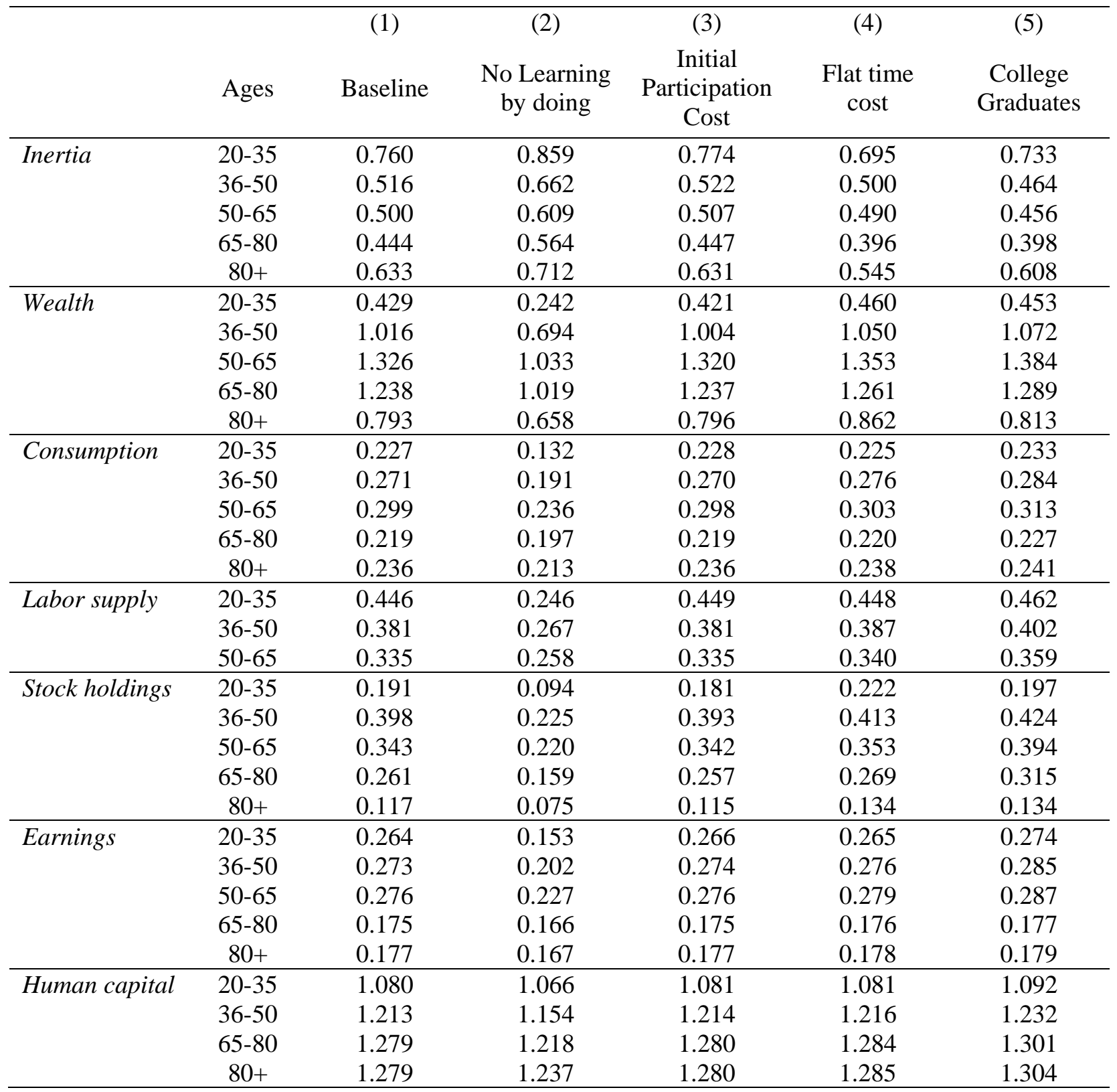

Notes: This table shows life cycle patterns of key variables for different model specifications. Column 1 uses baseline parameters as in Table 1. Columnn 2 shows results when human capital is deterministic over the life cycle, without learning by doing. Column 3 shows results when an investor must pay a fixed initial stock market participation cost in addition to recurring time cost. Column 4 provides results when the time cost of active management is set at 3\% for all ages. Column 5 shows results when the endogenous human capital process is matched with the wage trend $s$ for of college graduates in the PSID. 
Table 10: Sensitivity Analysis: Welfare Gains and Change in Portfolio Management Method with a Delegation Option (in percentage points)

A. Welfare Gain from a Delegation Option (\%)

\begin{tabular}{|c|c|c|c|}
\hline & $\begin{array}{l}\text { Baseline } \\
\text { (1) }\end{array}$ & $\begin{array}{l}\text { No minimum fee } \\
\text { (2) }\end{array}$ & $\begin{array}{l}\text { Current industy level } \\
\text { (3) }\end{array}$ \\
\hline Welfare Gain & 1.1897 & 1.4251 & 0.9886 \\
\hline
\end{tabular}

B. Sensitivity Analysis of Portfolio Management Methods (\%)

\begin{tabular}{llccc}
\hline & Ages & $\begin{array}{c}\text { Baseline } \\
(1)\end{array}$ & No minimum fee & $\begin{array}{c}\text { Current industry level } \\
(3)\end{array}$ \\
\hline Delegation & $20-35$ & 18.73 & $(2)$ & 1.84 \\
& $36-50$ & 20.45 & 33.57 & 5.10 \\
& $51-65$ & 20.81 & 33.09 & 7.73 \\
& $65+$ & 23.89 & 26.78 & 15.54 \\
\hline Inertia & $20-35$ & 73.39 & 31.13 & 75.78 \\
& $36-50$ & 50.87 & 64.38 & 51.77 \\
& $51-65$ & 49.30 & 49.15 & 50.44 \\
\hline Active & $20-35$ & 54.03 & 49.15 & 54.98 \\
\hline mgmt & $36-50$ & 7.87 & 50.32 & 22.37 \\
& $51-65$ & 28.68 & 2.05 & 43.13 \\
& $65+$ & 29.89 & 17.76 & 41.82 \\
\hline
\end{tabular}

Note: Panel A presents welfare gain/loss of having a delegation option versus a no-delegation base case, for alternative model specifications on minimum fixed delegation fees. Welfare Gain is the percentage increase in certainty-equivalent consumption stream compared to the no-delegation (baseline) case. Panel $\mathrm{B}$ describes the proportion of investors electing each portflio management method under different specifications on minimum fixed delegation. Delegation, Inertia, and Active mgmt refer to the proportions of investors choosing delegation, inertia, and active management, respectively. Column 1 shows baseline results with minimum fee of $\$ 2,115$ (commensumrate with a minimum balance of $\$ 150,000$ ). Column 2 provides results from having no minimum fee for delegation. Column 3 reports results from imposing a minimum fee commensurate with a higher required minimum balance $(\$ 243,360)$, consistent with the industry average. 
Figure 1: Life Cycle Profiles of Consumption, Earnings, Equity Share, Labor Supply, and Human Capital with No Delegation Option

A. Earnings, Consumption, and Total Wealth

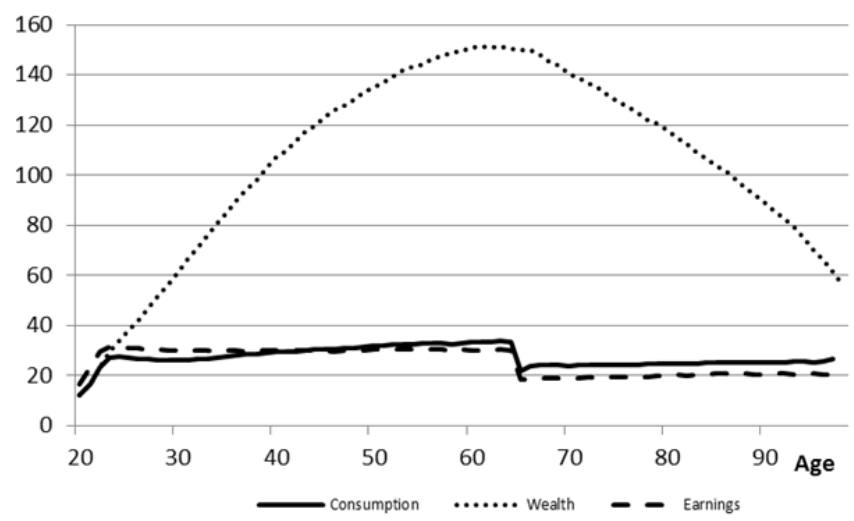

B. Stock Account Balance

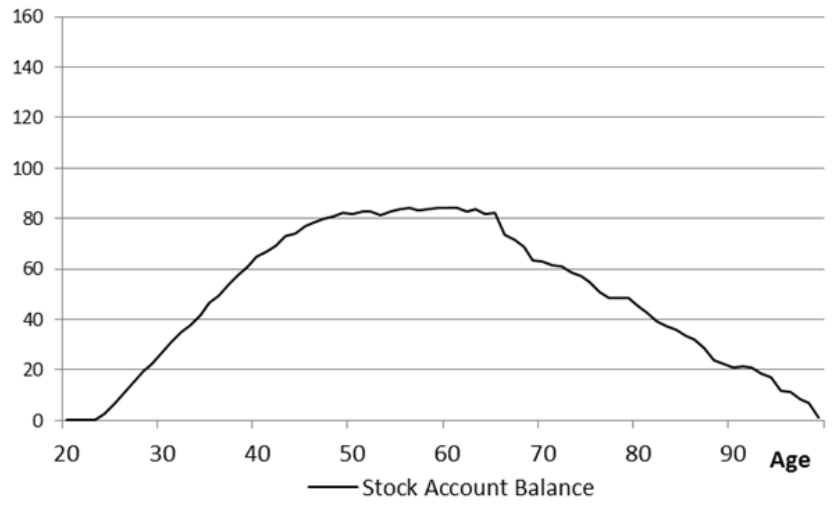

C. Labor Supply and Human Capital Accumulation

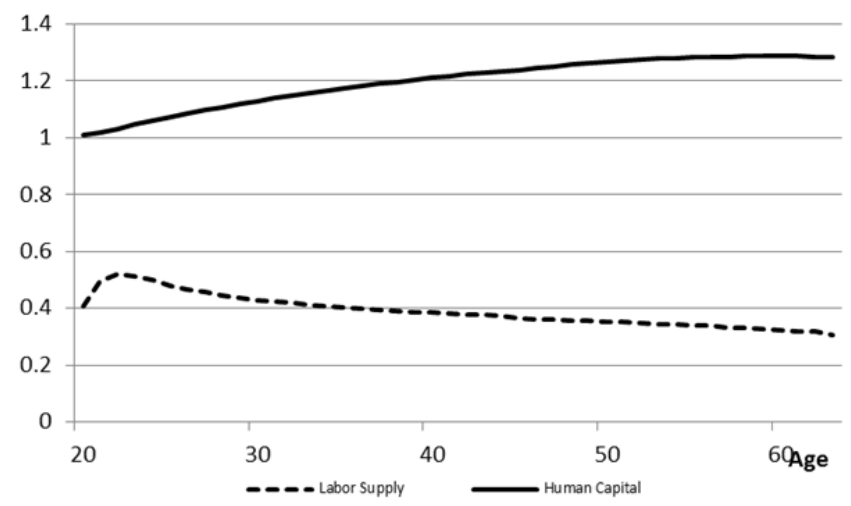

Notes: This Figure shows average life cycle profiles when only active management or inertia are feasible, generated from 2,000 independent simulations based on optimal feedback controls from the baseline specification of the life cycle model (see Table 1). Panel A displays average consumption, labor income and total wealth paths in 2012 US dollars (\$1,000s); Panel B shows the average amount of stock account balance in 2012 US dollars (\$1,000s); and Panel C depicts average work and human capital profiles. Human capital is normalized by the initial level. 
Figure 2: Choice of Portfolio Management Method and Equity Share Over the Life Cycle: No Delegation Option

A. Portfolio Management Method over the Life Cycle: No Delegation Option

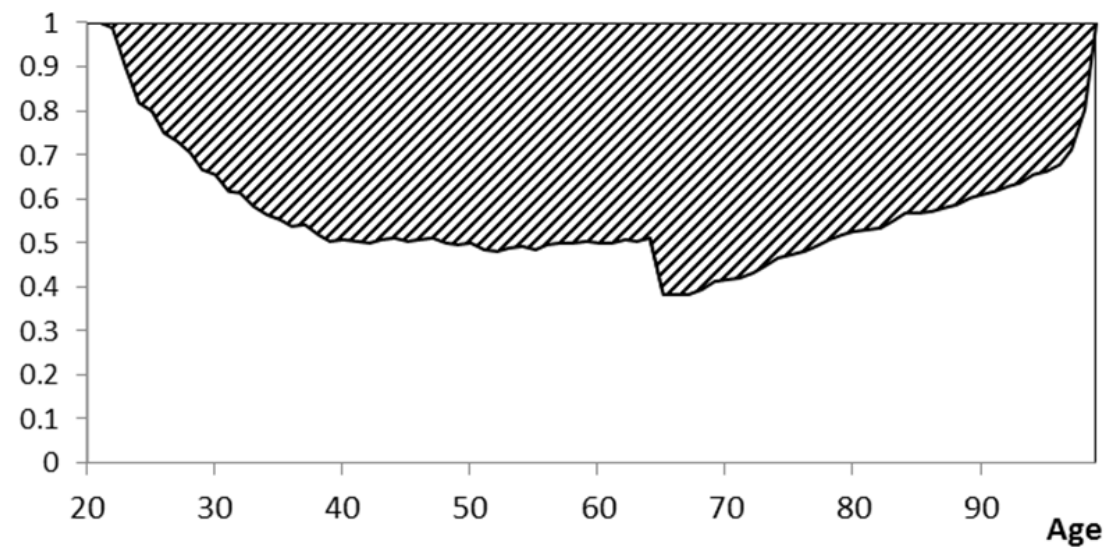

$\square$ Inertia $\square$ Active-management

B. Equity Shares Over the Life Cycle for Portfolio Management Method: No Delegation Option

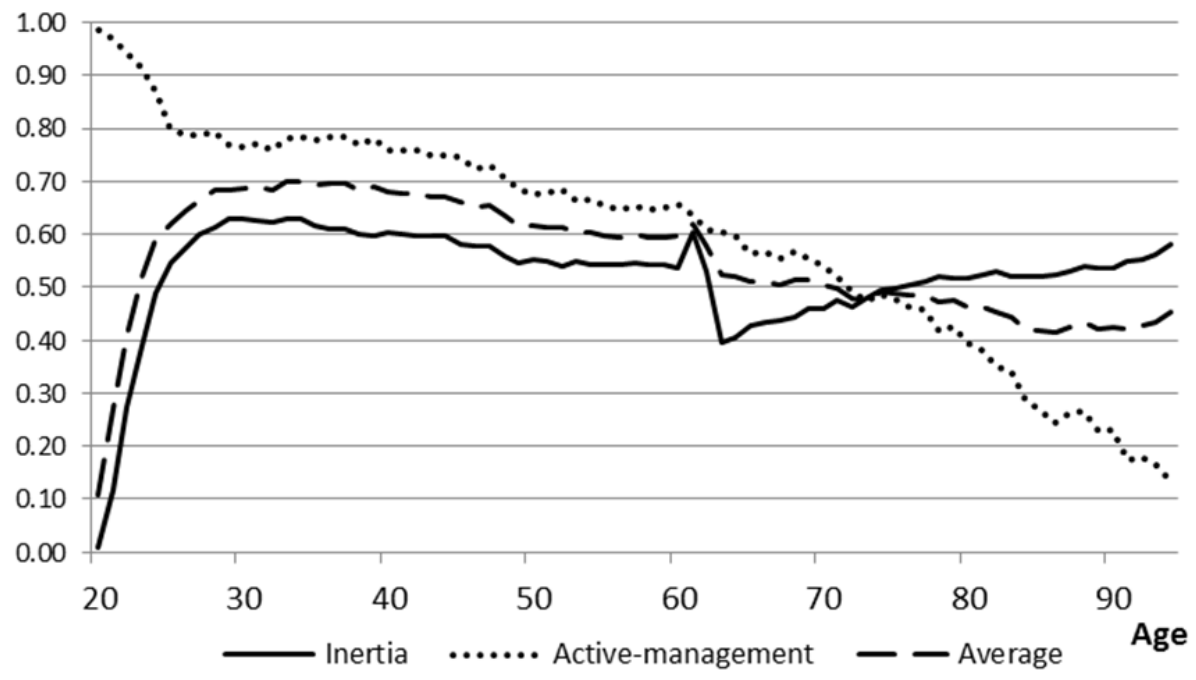

Notes: This figure shows life cycle patterns of portfolio management method and equity shares selected with no delegation option. Panel A shows the fraction of investors selecting inertia versus active management by age. Panel B shows the life cycle pattern of equity shares depending on whether the investor elects inertia or active management. Equity share is defined as stock holdings as a share of savings $\left(S_{t} /\left(S_{t}+B_{t}\right)\right)$ in period $t$ conditional on each portfolio management approach. Averages are generated from 2,000 independent simulations for individuals based on optimal feedback controls in the baseline specification of the life cycle model. 
Figure 3: Scatter Plot of Stock Balances Conditional on Portfolio Management Method: No Delegation Option

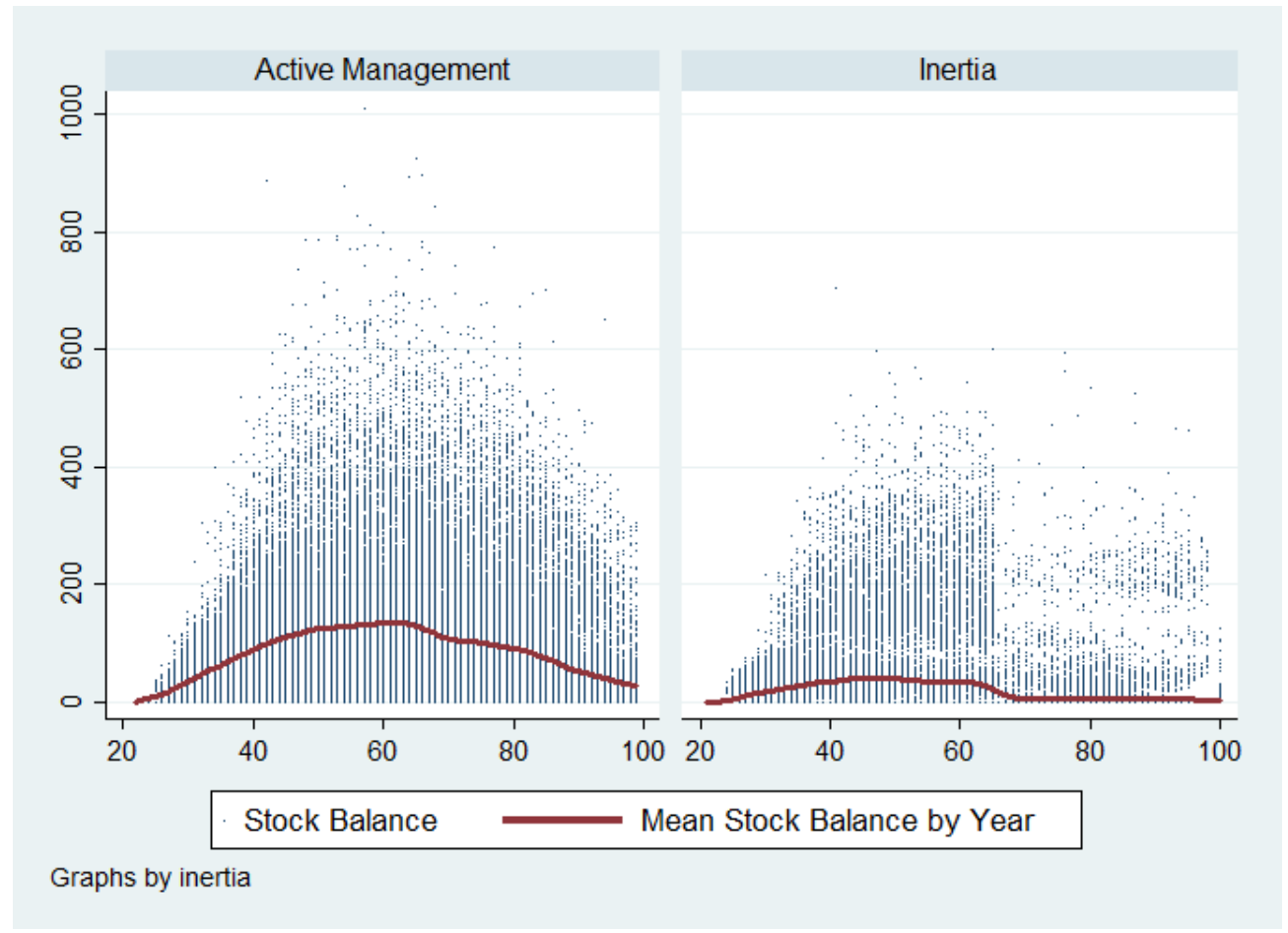

Notes: This figure shows a scatterplot of stock balances depending on whether the investor elected inertia or active management last period. The solid line indicates average stock balances for each portfolio management method. Averages generated from 2,000 independent simulations for individuals based on optimal feedback controls from the baseline specification. Account balance in 2012 US\$ (000). 


\section{Appendix A: Derivation of Financial Advisor Fees}

To evaluate fees charged by registered investment advisors (RIAs) in the U.S., we have tallied information from disclosure documents (Form ADV) filed with the U.S. Securities and Commissions (SEC) offic as of July 1, 2014. As is clear from Table A1, the percentage fee of total asset under management is the most common fee type used by financial advisors, though other charge structures are also found (percentages do not add to $100 \%$ as advisors use more than one fee structure).

We also explored who these advisors' clients were, and we found that most catered to individual investors. As we wished to get realistic fees for individual investors, we focused on advisors where individual clients comprised most (>three-quarters) of their practice of at least 100 clients. For our subsanple, the average percentage fee of total assets under management was $1.410 \%$ per year.

It is also worth noting that, for these advisors, minimum required account balances averaged around $\$ 240,000$. In our model, this threshold for adopting delegation would discourage almost all investors. Accordingly, we explore sensitivity to this choice by setting a lower account balance for delegation of $\$ 150,000$ in Section 6.

Table A1: Type of Fees Charged by U.S. Financial Advisors

\begin{tabular}{lc}
\hline Type of Advisory Fee & Number (\%) of advisers charging fee \\
\hline Percentage of asset under management & $10,727(94.7 \%)$ \\
Fixed fee (other than subscription fee) & $4,661(41.2 \%)$ \\
Performance-based fee & $4,354(38.5 \%)$ \\
Hourly charge & $3,174(28.0 \%)$ \\
Commission & $562(5.0 \%)$ \\
Subscription fee & $128(1.1 \%)$ \\
Other & $1,623(14.3 \%)$ \\
\hline
\end{tabular}

Notes: This table presents the fee structure for financial advisory service the US. Source: Calculated by authors from the Investment Advisor Public Disclosure (IAPD) Form ADV (part 1) of SEC-registered independent advisors as of July 1, 2014. As advisorsmore than one type of fees, we tally all types charged (so the columns do not sum to $100 \%$. 


\section{Appendix B. A Sufficient Condition for an Investor to Elect Portfolio Inertia}

Let $\left(l_{t}^{a, *}, S_{t}^{a, *}, C_{t}^{a, *}\right)$ and $\left(l_{t}^{i, *}, S_{t}^{i, *}, C_{t}^{i, *}\right)$ be maximizers of the objective functions of a active management method and a portfolio inertia method, respectively. The following implication holds:

Proposition. For any $\left(l_{t}^{a, *}, S_{t}^{a, *}, C_{t}^{a, *}\right)$ with $\max \left\{\left|l_{t}^{a, *}-l_{t}^{i, *}\right|,\left|C_{t}^{a, *}-C_{t}^{i, *}\right|\right\}<\left|S_{t}^{a, *}-Z_{t}\right|$, there exists $\quad \delta^{*}>0 \quad$ such that $\forall S_{t}^{a, *} \quad$ with $\left|S_{t}^{a, *}-Z_{t}\right|<\delta^{*} \quad$ implies $V_{t}^{i}\left(X_{t}, H_{t}, Z_{t}, y_{t}\right)>V_{t}^{a}\left(X_{t}, H_{t}, Z_{t}, y_{t}\right)$.

\section{Proof:}

We define the excess value of choosing inertia portfolio over active management method as:

$$
\begin{array}{r}
\tilde{V}_{t}\left(l_{t}, S_{t}, C_{t} ; W_{t}, H_{t}, Z_{t}, y_{t}\right) \equiv V_{t}^{i}\left(l_{t}, S_{t}, C_{t} ; W_{t}, H_{t}, Z_{t}, y_{t}\right)-V_{t}^{a}\left(l_{t}, S_{t}, C_{t} ; W_{t}, H_{t}, Z_{t}, y_{t}\right) \\
=V_{t}^{i}\left(l_{t}, S_{t}, C_{t} ; W_{t}, H_{t}, Z_{t}, y_{t}\right)-\left\{u\left(C_{t}, 1-l_{t}-\phi_{t}\right)+p_{t} \beta \mathbb{E}_{t}\left[V_{t+1}\left(W_{t+1}, H_{t+1}, Z_{t+1}, y_{t+1}\right)\right]\right\}
\end{array}
$$

For choices variables making inertia superior $\left(l_{t}^{i, *}, S_{t}^{i, *}, C_{t}^{i, *}\right)$ over active management, the excess value of choosing inertia becomes

$$
\tilde{V}_{t}\left(l_{t}^{i, *}, S_{t}^{i, *}, C_{t}^{i, *} ; W_{t}, H_{t}, Z_{t}, y_{t}\right)=u\left(C_{t}^{i, *}, 1-l_{t}^{i, *}\right)-u\left(C_{t}^{i, *}, 1-\phi_{t}-l_{t}^{i, *}\right)>0
$$

because the continuation values for inerita and active management method $\left(V_{t+1}(\cdot)\right)$ will be same and the utility function $u$ is increasing in leisure time. Since $\tilde{V}_{t}\left(\cdot ; W_{t}, H_{t}, Z_{t}, y_{t}\right)$ is continuous in $\left(l_{t}, S_{t}, C_{t}\right)$, then $\exists \delta>0$ such that $\forall\left(l_{t}, S_{t}, C_{t}\right)$ with $d\left[\left(l_{t}, S_{t}, C_{t}\right),\left(l_{t}^{i, *}, S_{t}^{i, *}, C_{t}^{i, *}\right)\right]<\delta$, we have $\tilde{V}_{t}\left(l_{t}, S_{t}, C_{t} ; W_{t}, H_{t}, Z_{t}, y_{t}\right)>0$. Choose $\delta^{*}=\sqrt{\frac{\delta}{3}}$. By the assumption that $\max \left\{\mid l_{t}^{a, *}-\right.$ $\left.l_{t}^{i, *}|,| C_{t}^{a, *}-C_{t}^{i, *} \mid\right\}<\left|S_{t}^{a, *}-Z_{t}\right|$, the condition $\left|S_{t}^{a, *}-Z_{t}\right|<\delta^{*}$ implies:

$$
\left|l_{t}^{a, *}-l_{t}^{i, *}\right|^{2}+\left|S_{t}^{a, *}-Z_{t}\right|^{2}+\left|C_{t}^{a, *}-C_{t}^{i, *}\right|<3\left(\delta^{*}\right)^{2}=\delta
$$

Plugging in $\left(l_{t}^{a, *}, S_{t}^{a, *}, C_{t}^{a, *}\right)$ into the excess value of choosing inertia, we have the following:

$$
\begin{aligned}
& V_{t}^{i}\left(l_{t}^{a, *}, S_{t}^{a, *}, C_{t}^{a, *} ;\right.\left.W_{t}, H_{t}, Z_{t}, y_{t}\right) \\
&-\left\{u\left(C_{t}^{a, *}, 1-l_{t}^{a, *}-\phi_{t}\right)+p_{t} \beta \mathbb{E}_{t}\left[V_{t+1}\left(W_{t+1}, H_{t+1}, Z_{t+1}, y_{t+1}\right]\right\}>0\right.
\end{aligned}
$$

and the latter part is $V_{t}^{a}\left(W_{t}, H_{t}, Z_{t}, y_{t}\right)$ because $\left(l_{t}^{a, *}, S_{t}^{a, *}, C_{t}^{a, *}\right)$ is the solution of active management method. So we showed $V_{t}^{i}>V_{t}^{a}$ for all $S_{t}^{a, *}$ with $\left|S_{t}^{a, *}-Z_{t}\right|<\delta^{*}$.

QED

Discussion:

If next period's labor and consumption levels resulting from porfolio active management are very similar to those resulting from inertia, there will be a 'dominant boundary of portfolio inertia' where inertia will be preferred to active management. In other words, if an investor expects he will end up choosing a similar consumption/labor supply pair next period, a small change in his portfolio will be costly without enhancing his discounted lifetime utility. In such a case, it will then be optimal for him not to alter his portfolio. 


\section{Appendix C. Numerical Solution Procedure ${ }^{35}$}

Here we describe our procedure for obtaining the numerical solution to the investor's problem. In the last period of life $T$, assuming $V_{T+1}=0$ and $a_{T}=0$ (inertia), the investor maximizes his utility by consuming his available liquid assets $\left(W_{T}-Z_{T}\right)$ for every pair of state variables $\left(W_{T}, H_{T}, Z_{T}, y_{T}\right)$. In period $T-1$, we calculate $V_{T-1}^{i}, V_{T-1}^{a}, V_{T-1}^{d}$ using their definitions and the Monte Carlo integration (based on 50 runs) of $\mathbb{E}_{T-1}\left[V_{T}\left(W_{T}, H_{T}, Z_{T}, y_{T}\right)\right]$, as well as Nelder-Mead optimization over $\left(l_{T-1}, S_{T-1}, c_{T-1}\right)$. Of course, $S_{T-1}=Z_{T-1}$ in calculating $V_{T-1}^{i}$. We approxiate value functions using multi-linear interpolation for state variables not contained in the discretized set of grids (see Brandt et al. 2005).

Accordingly, we get $V_{T-1}\left(W_{T-1}, H_{T-1}, Z_{T-1}, y_{T-1}\right)=\max \left\{V_{T-1}^{i}, V_{T-1}^{a}, V_{T-1}^{d}\right\}$. When $V_{T-1}^{i}=\max \left\{V_{T-1}^{i}, V_{T-1}^{a}, V_{T-1}^{d}\right\}$, portfolio inertia is optimal. Different choices of management method are derived similarly. Iterating these steps until the first period, we get the value functions $\left\{V_{t}\right\}_{t=1}^{T}$ which completely characterize the solution to the investor's problem. Last, we generate 2,000 sample paths for individual investors using variations of the wage shock and uncertain stock market returns

For multi-linear interpolation, we extend a one-variable linear interpolation to a multivariable setting. Given a current state $\left(W_{t}, H_{t}, Z_{t}, y_{t}\right)$, the next period's realized state $\left(\widetilde{W}_{t+1}, \widetilde{H}_{t+1}, \tilde{Z}_{t+1}, \tilde{y}_{t+1}\right)$ is determined by the current period's choices (portfolio management method: $a_{t}$, labor supply: $\mathrm{l}_{\mathrm{t}}$, equity investment amount: $\mathrm{S}_{\mathrm{t}}$, and consumption: $\mathrm{C}_{\mathrm{t}}$ ) and exogenous shocks (stock return: $\tilde{R}_{\mathrm{t}}$, shock to human capital: $\lambda_{\mathrm{t}}$ and persistent/transitory wage shock). It is possible that the realized state variable set $\left(\widetilde{W}_{t+1}, \widetilde{H}_{t+1}, \widetilde{Z}_{t+1}, \tilde{y}_{t+1}\right)$ does not belong to a set of discretized state variables $\left\{W_{t+1}^{i}, H_{t+1}^{j}, Z_{t+1}^{k}, y_{t+1}^{l}\right\}_{i, j, k, l}$ in the next period. To address this issue, we find adjacent two state variables for each realized state variable. For example, for a potential wealth level $\left(\widetilde{W}_{t+1}\right)$ in the next period, we find nearest two grid points, $W_{t+1}^{1}$ and $W_{t+1}^{2}$ among discretized wealth grids $\left\{W_{t+1}\right\}$ such that $W_{t+1}^{1} \leq \widetilde{W}_{t+1} \leq W_{t+1}^{2}$. For a realized set of state variables $\left(\widetilde{W}_{t+1}, \widetilde{H}_{t+1}, \tilde{Z}_{t+1}, \tilde{y}_{t+1}\right)$, there will be 16 sets of close state variables $\left\{\left\{W_{t+1}^{1}, W_{t+1}^{2}\right\},\left\{H_{t+1}^{1}, H_{t+1}^{2}\right\},\left\{Z_{t+1}^{1}, Z_{t+1}^{2}\right\},\left\{y_{t+1}^{1}, y_{t+1}^{2}\right\}\right\}$ for which we know the value of value functions $\left\{V_{t+1}\left(W_{t+1}^{1}, H_{t+1}^{1}, Z_{t+1}^{1}, y_{t+1}^{1}\right), \ldots, V_{t+1}\left(W_{t+1}^{2}, H_{t+1}^{2}, Z_{t+1}^{2}, y_{t+1}^{2}\right)\right\} \quad$ by preceding backward value function iterations.

The value of $\mathrm{V}_{\mathrm{t}+1}\left(\widetilde{W}_{t+1}, \widetilde{H}_{t+1}, \widetilde{Z}_{t+1}, \tilde{y}_{t+1}\right)$ will be determined by a weighted sum of value functions of nearest state variables. We use the inverse of distance between realized state variables and each set of close state variables as a weight for the corresponding value function. Denote $\mathrm{D}_{i, j, k, l}$ as the distance from $\left(\widetilde{W}_{t+1}, \widetilde{H}_{t+1}, \widetilde{Z}_{t+1}, \tilde{y}_{t+1}\right)$ to $\left\{W_{t+1}^{i}, H_{t+1}^{j}, Z_{t+1}^{k}, y_{t+1}^{l}\right\}$, which is defined as the ordinary Euclidean distance:

$$
\mathrm{D}_{i, j, k, l}=\sqrt{\left(\widetilde{W}_{t+1}-W_{t+1}^{i}\right)^{2}+\left(\widetilde{H}_{t+1}-H_{t+1}^{j}\right)^{2}+\left(\tilde{Z}_{t+1}-Z_{t+1}^{k}\right)^{2}+\left(\tilde{y}_{t+1}-y_{t+1}^{l}\right)^{2}} .
$$

The corresponding weight $\left(g_{i, j, k, l}\right)$ is constructed as

35 This numerical procedure is implemented with FORTRAN90 and the GNU Gfortran compiler. 


$$
g_{i, j, k, l} \equiv \frac{\frac{1}{\mathrm{D}_{i, j, k, l}}}{\sum_{i=1}^{2} \sum_{j=1}^{2} \sum_{k=1}^{2} \sum_{l=1}^{2} \frac{1}{\mathrm{D}_{i, j, k, l}}}
$$

Thus, the further distant the nearby state variables are from the realized state, the less weight will be assigned to its value function. And of course, the sum of weights is equal to one by construction $\left(\sum g_{i, j, k, l}=1\right)$.

The value of $\mathrm{V}_{t+1}\left(\widetilde{W}_{t+1}, \widetilde{H}_{t+1}, \tilde{Z}_{t+1}, \tilde{y}_{t+1}\right)$ is estimated as a weighted sum of adjacent value functions:

$$
\mathrm{V}_{\mathrm{t}+1}\left(\widetilde{W}_{t+1}, \widetilde{H}_{t+1}, \tilde{Z}_{t+1}, \tilde{y}_{t+1}\right)=\sum_{i=1}^{2} \sum_{j=1}^{2} \sum_{k=1}^{2} \sum_{l=1}^{2} g_{i, j, k, l} V_{t+1}\left(W_{t+1}^{i}, H_{t+1}^{j}, Z_{t+1}^{k}, y_{t+1}^{l}\right)
$$

The above interpolation method is implemented both in VFI and simulations finding the maximized future continuous values and corresponding maximal choice variables (i.e., portfolio management method, labor supply, equity investment, consumption). In the course of implementation, we impose a restriction that the equity balance cannot exceed total wealth $\left(W_{t+1}^{i} \geq Z_{t+1}^{k}\right)$. 


\section{Appendix D. Calibrating the Learning by Doing Mechanism}

This Appendix explains how we calibrate the parameters in the learning by doing mechanism. We first estimated the parameters by matching wage profiles generated by a learning by doing mechanism with the conventional wage profile in the life cycle portfolio choice literature (e.g., Gomes and Michaelides 2005; Cocco et al. 2005). To be precise, we generated 3,000 life cycle wage paths based on age-dependent wage trend for male high school graduates, assuming an idiosyncratic wage shock and a permanent wage shock with the parameters reported in Hubener et al. (2013). We also generate 3,000 life cycle paths of wages based on our learning by doing mechanism (formula (2)), allowing varying levels of skill formation uncertainty ( $\lambda$ ), the depreciation rate for human capital, learning efficiency (a), returns to scale $(\theta)$, and idiosyncratic and permanent wage shocks with an assumed level of average labor supply level (0.35).

For each potential candidate set of parameters, we calculated moment conditions by year of age including average and standard deviation of wages, skewness and kurtosis of mean wages, and maximum and minimum average wages. Then we estimated these parameters by minimizing the numerical distance between moment conditions generated by learning by doing mechanism with labor market shocks and moment conditions generated by the conventional wage profile as in Hubener et al. (2013). An illustration of the match is presented below.

Figure A1: A normalized wage profile matched with the empirical wage profile

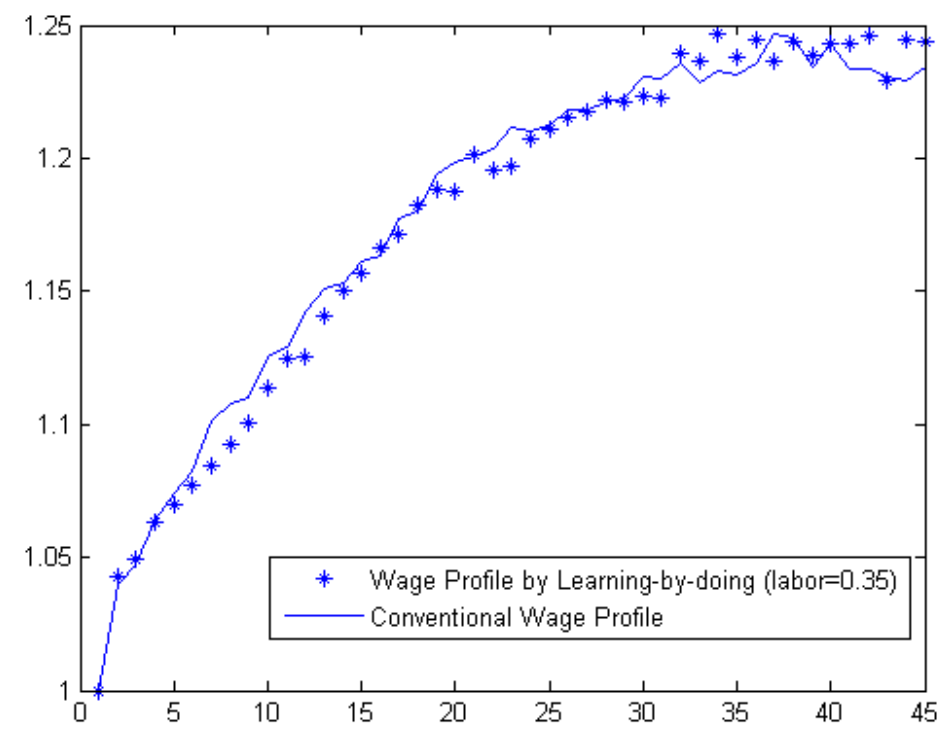

Note: This figure shows patterns of average wage profiles generated by the human capital accumulation process with labor market shocks (dotted line) and the empirical data from the PSID (solid line). The wage path is normalized by the first year's wage. 